Digitized by the Internet Archive in 2011 with funding from

University of Illinois Urbana-Champaign 
ILLINOIS

NATURAL

HISTORY

S UR VEY

\section{Annotated Catalog of Type Specimens in the Illinois Natural History Survey Fish Collection.}

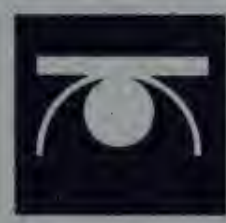

Mark H. Sabaj; Kevin S. Cummings, and Lawrence M. Page

Illinois Natural History Survey Bulletin Volume 35, Article 5

October 1997 
Illinois Natural History Survey, Edward J. Armbrust, Acting Chief A Division of the Illinois Department of Natural Resources

A catalog of the publications of the Illinois Natural.History Survey is available without charge from the address below: A price list and an order blank are included with the catalog.

Illinois Natural History Survey

Distribution Center

Natural Resources Building

607 East Peabody Drive

Champaign, Illinois 61820

\section{Citation:}

Sabaj, M.H., K:S. Cummings, and L.M. Page. 1997. Annotated Catalog of Type Specimens in the Illinois Natural History Survey Fish Collection. Illinois

Natural History Survey Bulletin 35(5):253-300.

Editor: Thomas E. Rice

US ISSiN 0073-4918.

Printed by Authority of the State of Illinois (SR737123-1.5M-10-97) 
ILLINOIS

NATURAL

HISTORY

S UR VEY

\section{Annotated Catalog of Type Specimens in the Illinois Natural History Survey Fish Collection}

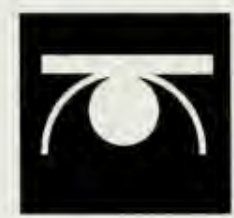

Mark H. Sabaj, Kevin S. Cummings, and Lawrence M. Page Center for Biodiversity

Illinois Natural History Survey

Illinois Natural History Survey Bulletin

Volume 35, Article 5

October 1997
NATURAL HISTORY SURVEY

JAN 291999

LIBRARY 



\title{
Contents
}

\author{
Acknowledgments iv \\ Introduction 253 \\ Facilities and Curation 253 \\ General Holdings 253 \\ Type Holdings 254 \\ Organization 255 \\ General Format 255 \\ List of Types 260 \\ ACIPENSERIDAE 260 \\ CYPRINIDAE 260 \\ CHARACIDAE 269 \\ ICTALURIDAE 269 \\ LORICARIIDAE 270 \\ APHREDODERIDAE 272 \\ AMBLYOPSIDAE 273 \\ OPHIDIIDAE 274 \\ FUNDULIDAE 274 \\ CENTRARCHIDAE 275 \\ PERCIDAE 277 \\ ELASSOMATIDAE 285 \\ ISLNH Types Missing from INHS 285 \\ CYPRINIDAE 285 \\ CATOSTOMIDAE 288 \\ PERCIDAE 289 \\ COTTIDAE 291 \\ Literature Cited 292
}




\section{Acknowledgments}

We would like to thank William N. Eschmeyer, California Academy of Sciences, and Carter R. Gilbert, Florida Museum of Natural History, for comments and suggestions on improving the manuscript. We would also like to thank Christine A. Mayer for assistance with INHS database records. Special thanks to Susan L. Jewett for assistance while visiting the U.S. National Museum of Natural History and Jeffrey T. Williams for advice on using the USNM online database. 


\section{Annotated Catalog of Type Specimens in the Illinois Natural History Survey Fish Collection}

The Fish Collection of the Illinois Natural History Survey (INHS) dates back to the late 1800 s and the extensive surveys of Illinois fishes led by Dr. Stephen A. Forbes, director of the Survey's predecessor, the Illinois State Laboratory of Natural History (ISLNH). From 1876 to 1903 Forbes, assisted by his esteemed colleague Robert E. Richardson and numerous field and laboratory personnel, collected and preserved over 200,000 specimens from more than 450 localities distributed in 93 of the 102 counties of Illinois. During this time, the ISLNH Collection served as the basis for several catalogs of Illinois fishes (Nelson 1876; Jordan 1878a; Forbes 1884; Large 1903), and provided material for the description of at least 25 species. This work culminated in the classic Fishes of Illinois written by Forbes and Richardson, published by the Survey in 1909 and reprinted in 1920 (although no publication date is given for the original volume, H.C. Oesterling, former INHS editor, lists the date as 1909 in Howard 1932:46). Accompanied by a separate atlas of distribution maps of 98 species, this comprehensive treatment of the state's ichthyofauna still is recognized as one of the finest publications on fishes.

The INHS Fish Collection was expanded by Dr. Philip W. Smith, who worked as a systematic biologist at the Survey from 1942 until his retirement in 1979 (Burr and Page 1987). Over a period of 11 years from 1962 to 1972, Smith assembled a large collection of fishes from Illinois and neighboring states. The ichthyological surveys conducted by Smith, his students, and INHS staff led to the publication of a second Fishes of Illinois (Smith 1979).

Smith's monograph provided identification keys, information on the ecology and taxonomy of Illinois fishes, and detailed distribution maps that documented changes in the state's fish fauna that had occurred since the survey of Forbes and Richardson.

The size and geographic scope of the INHS collection have been considerably expanded in the past three decades; the collection now contains about 711,000 cataloged specimens (over 71,000 lots) of more than 1,800 species. A recent literature survey identified over 250 publications citing the use of INHS specimens over the past 40 years. Included are two publications that have greatly advanced both the professional and popular understanding of North American fishes: the Handbook of Darters (Page 1983) and A Field Guide to Freshwater Fishes of North America North of Mexico (Page and Burr 1991).

\section{Facilities and Curation}

Despite its long history, the INHS Fish Collection has had only three curators: Dr. Stephen A. Forbes (1876-1930), Dr. Philip W. Smith (1950-1979), and Dr. Lawrence M. Page (1972present); and two collection managers, Kevin S. Cummings (1983-1995) and Mark H. Sabaj (1995-present). Currently staffed and supported by the INHS Center for Biodiversity, the collection occupies 888 square feet in the basement of the Natural Resources Building, 607 East Peabody Drive, Champaign, Illinois 61820.

Computerization of the INHS collection began in 1974 and was completed in 1990. The database is maintained by database manager Christine A. Mayer (1987-present) and will be accessible on the INHS Collections home page via the World Wide Web in 1998.

\section{General Holdings}

As of June 1997, the INHS Fish Collection contained approximately 711,000 cataloged specimens in over 71,000 lots representing 143 families and more than 1,800 species. It was ranked the 19th largest fish collection by lots (U.S. and Canada) in 1995 (Poss and Collette 1995) and the 8th largest collection of Neotropical fishes in North America in 1994 
(NEODAT WWW site). Approximately half of the specimens are from Illinois; the remainder are from elsewhere in North America (30\%), South America (18\%), and the rest of the world (2\%). The North American ichthyofauna is represented by collections from 47 of the 50 states, Canada, Mexico, Costa Rica, Panama, and Puerto Rico. The South American material includes specimens from Bolivia, Brazil, Peru, and Venezuela. The value of the INHS collection is greatly enhanced by historical holdings of Illinois fishes dating from 1873 to 1909. Referred to as the "Forbes and Richardson Collection," this material $(20,385$ specimens in 2,624 lots) represents about $10 \%$ of the original ISLNH fish collection and includes many species now extirpated or rare in Illinois.

The oldest specimen in the INHS collection is a sturgeon, Acipenser stellatus Pallas 1771, from the Ural River, former Soviet Union, collected by Dr. Lewerzow in 1862. This specimen and several other Soviet sturgeons were donated to ISLNH by Dr. Leo $\mathrm{S}$. Berg from the Zoological Museum of the Academy of Sciences of U.S.S.R. in Leningrad [= St. Petersburg]. Berg was an eminent teacher and ichthyologist who specialized in the classification and systematics of sturgeons (Family Acipenseridae). The donation was probably in exchange for syntypic material sent to Berg of the pallid sturgeon, Scaphirhynchus albus, a species described from Illinois by Forbes and Richardson in 1905. Also of exceptional value is a specimen of the harelip sucker, Moxostoma lacerum (Jordan and Brayton 1877), collected from Cypress Creek (Tennessee River drainage), Alabama. Received from C.H. Gilbert, the specimen was collected during his ichthyological explorations of Alabama in the summer of 1889 (Gilbert 1891:147). The harelip sucker is the first and most widespread fish to have become extinct in the United States in modern times (Williams 1977). Jenkins (in Jenkins and Burkhead 1994) noted that there are only 33 extant nonfossil specimens (deposited in 10 museums), and only 19 or 20 recorded captures of the harelip sucker spanning the years 1859 to 1893 .

\section{Type Holdings}

The INHS Fish Collection contains 967 type specimens representing 69 nominal species and

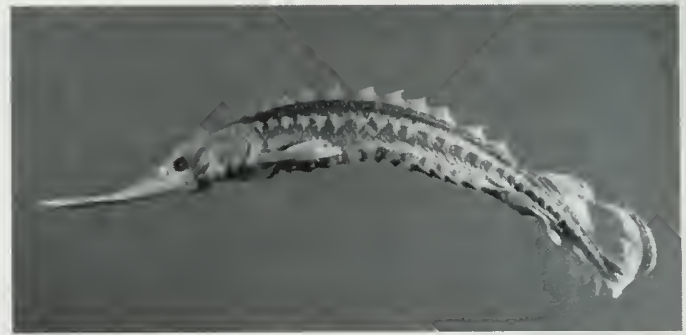

Acipenser stellatus Pallas 1771. Oldest specimen in INHS Fish Collection. INHS 64423, Ural River, former U.S.S.R.; Dr. Lewerzow; 1862.

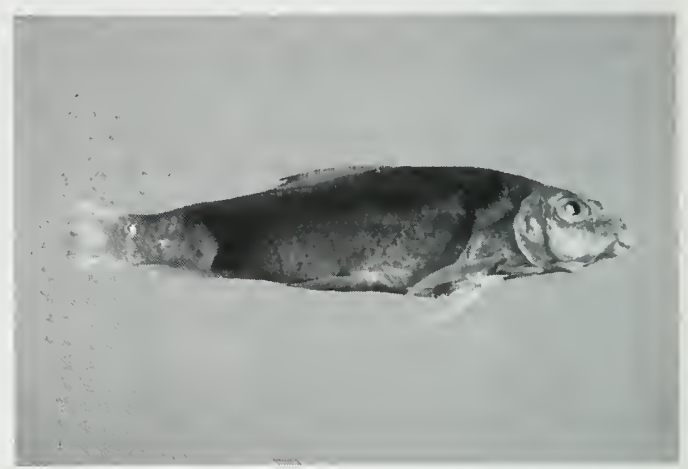

Moxostoma lacerum (Jordan and Brayton 1877). Extinct species of North American sucker represented in museums by only 33 known nonfossil specimens (Jenkins and Burkhead 1994). INHS 27884, Cypress Creek, Florence, Lauderdale County, Alabama; C.H. Gilbert; summer 1889.

2 nominal subspecies (Table I). Name-bearing type material includes 26 holotypes ( 24 nominal species, 2 subspecies), 5 lectotypes, and 5 series of syntypes ( 39 specimens). Additional type material includes paratypes of 63 nominal species ( 883 specimens) and 2 subspecies (14 specimens).

P.W. Smith and D.W. Bridges (1960) compiled the first type catalog of specimens formerly of the Illinois State Laboratory of Natural History. They identified types of 11 nominal species; ISLNH types of 4 additional species are documented in this paper. The State Laboratory type material represents species described from Illinois from 1876 to 1905 by Stephen A. Forbes ( 9 species), Forbes and Robert E. Richardson (1), David Starr Jordan (2), Edward W. Nelson (2), and Jordan and Nelson (1). A number of type specimens were presumably deposited in the State 
Laboratory Collection but are not presently found in the Survey's Collection. This lost material includes types of species described by Forbes (4), Jordan (1), Jordan and A.W.

Brayton (1), and Nelson (5 species +1 variety).

Table 2 summarizes the status and disposition of type specimens of taxa described from Illinois from 1876 to 1905 . The type localities of these taxa are plotted on Map 1.

\section{Organization}

This catalog is divided into two sections: (1) type specimens presently located in the Fish Collection of the Illinois Natural History Survey (INHS), and (2) type specimens originally deposited in the Illinois State Laboratory of Natural History (ISLNH), but not currently found in the INHS collection (i.e., species whose types are either missing entirely or represented only by ISLNH specimens donated to other museums). In both sections, species and subspecies are presented alphabetically within families, and the families are arranged phylogenetically according to Nelson (1994). Photographs of type specimens are presented for 15 species described between 1876 and 1905 by S.A. Forbes, D.S. Jordan,
E.W. Nelson, and R.E. Richardson. Except for Parascaphirhynchus albus Forbes and Richardson 1905, these species were not figured in their original description and photographs of the type specimens have never been published.

\section{General Format}

Species name Author(s) year.

Literature citation: page number, plate(s), figure(s).

Type status

\section{museum acronym and catalog number (number of specimens, length, sex); locality; collector(s) (field collection number); date; former museum acronym and catalog number. Information in brackets was not in the original description but has been added for completeness.}

Remarks: Clarification and correction of data; explanation and documentation of type status; comments on current condition of specimens.

Missing: Type specimens originally cataloged at ISLNH, but whose precise locality is currently unknown.

Table 1. Summary of type material in the Illinois Natural History Survey Fish Collection.

\begin{tabular}{|c|c|c|c|c|}
\hline \multirow{2}{*}{$\begin{array}{l}\text { current status of } \\
\text { taxonomic name }\end{array}$} & \multicolumn{3}{|c|}{ name-bearing types } & \multirow[b]{2}{*}{ Paratypes } \\
\hline & Holotypes & Lectotypes & Syntypes & \\
\hline \multicolumn{5}{|l|}{ species } \\
\hline in use & 22 & 3 & 2 & 60 \\
\hline & & & 12 specimens in 3 lots & 836 specimens in 87 lots \\
\hline \multirow[t]{2}{*}{ in synonymy } & 1 & 1 & 3 & 3 \\
\hline & & & 27 specimens in 4 lots & 47 specimens in 6 lots \\
\hline based on hybrid & 1 & 1 & - & - \\
\hline \multicolumn{5}{|l|}{ subspecies } \\
\hline \multirow[t]{2}{*}{ in use } & 2 & - & - & 2 \\
\hline & & & & 14 specimens in 3 lots \\
\hline total number of & 26 & 5 & 5 & 65 \\
\hline taxa represented & & & 39 specimens in 7 lots & 897 specimens in 86 lots \\
\hline
\end{tabular}


Table 2. Status and disposition of type specimens of taxa described from Illinois from 1876 to 1905. Location(s) of type lot(s) indicated by museum acronym followed by the number of specimens per lot(s) in parentheses.

\section{Author date}

original name

current name

name-bearing types
Holotype $\quad$ Lectotype $\quad$ Paralectotypes

\section{Nelson 1876}

- Noturis exilis

- Stemotremia isolepis

Noturus exilis

Aphredoderus sayanus

INHS

Phenacobius teretulus var. liosternus

Ichthyobus cyanellus

Phenacobius mirabilis

INHS

INHS (2), MCZ (1),

USNM (1)

Etheostoma phoxocephalum Percina phoxocephala

Cottopsis ricei

Cottus ricei

missing

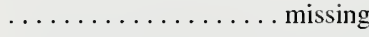

UMMZ (2)

Jordan and Nelson 1877

- Lepiopomus ischyrus

\section{Lepomis cyanellus $x$}

INHS

Lepomis macrochirus

\section{Nelson 1877}

\section{Ichthyobus ischyrus}

Bubalichthys altus

Ictiobus bubalus

Ictiobus bubalus

\section{Forbes 1878}

- Episema jejuna

- Alburnops nubilus Poecilichtlys asprigenis Boleosoma camurum

\section{Jordan 1878}

- Cyprinella forbesi

- Pleurolepis asprellis Lythrurus atripes

\section{Forbes 1882}

- Chologaster papilliferus

Forbesichthys agassizi

INHS (3, 1), MCZ (1)

\section{Forbes 1883}

- Trycherodon megalops

- Platygobio pallidus

- Leponis symmetricas

Opsopoeodus emiliae

Platygobio gracilis

Lepomis symmetricus

Notropis blennius

Notropis mubilus

Etheostoma asprigene

Etheostoma chlorosomum

Cyprinella lutrensis

Crystallaria asprella

Lythrurus umbratilis

\section{INHS}

USNM INHS $(6,21)$, CAS (2)

INHS $(6, \mathrm{I})$

CAS (2)

CAS (1), MCZ (I),

$\operatorname{UMMZ}(1), \operatorname{USNM}(1,2)$

missing

USNM CAS (2)

\section{Forbes 1885}

- Notropis anogenus Notropis anogenus

- Oxygeneum pulverulentum Campostoma anomalum $x$
- Lepomis garmani Notropis macrolepidotus Notropis plenacobius

Phoxinus erythrogaster

Lepomis miniatus

Lythrurus fumeus

Hybopsis amnis

\begin{tabular}{|c|c|c|}
\hline & USNM & $\begin{array}{l}\text { INHS }(13,1,4) \\
\text { CAS }(1)\end{array}$ \\
\hline 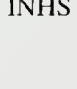 & INHS & $\begin{array}{r}\operatorname{INHS}(7,2), \operatorname{MCZ}(1) \\
\text { CAS (3), USNM (1) }\end{array}$ \\
\hline
\end{tabular}

\section{INHS}

INHS INHS (5), USNM (7)

Forbes and Richardson 1905

- Parascaphirhynchus albus

Scapliirliynchus albus

\section{INHS (5)}




\section{Map 1: Type localities of species described from Illinois from 1876 to 1905.}

Unspecified type localities depicted by multiple dots, shaded outline of county, or highlighted stretch of stream. Base map from Forbes and Richardson 1909.

Not Mapped Notropis macrolepidotus (= Lythrurus fumeus) Type Locality: Illinois River Etheostoma phoxocephalum (= Percina phoxocephala) Type Locality: Western Illinois including Illinois River

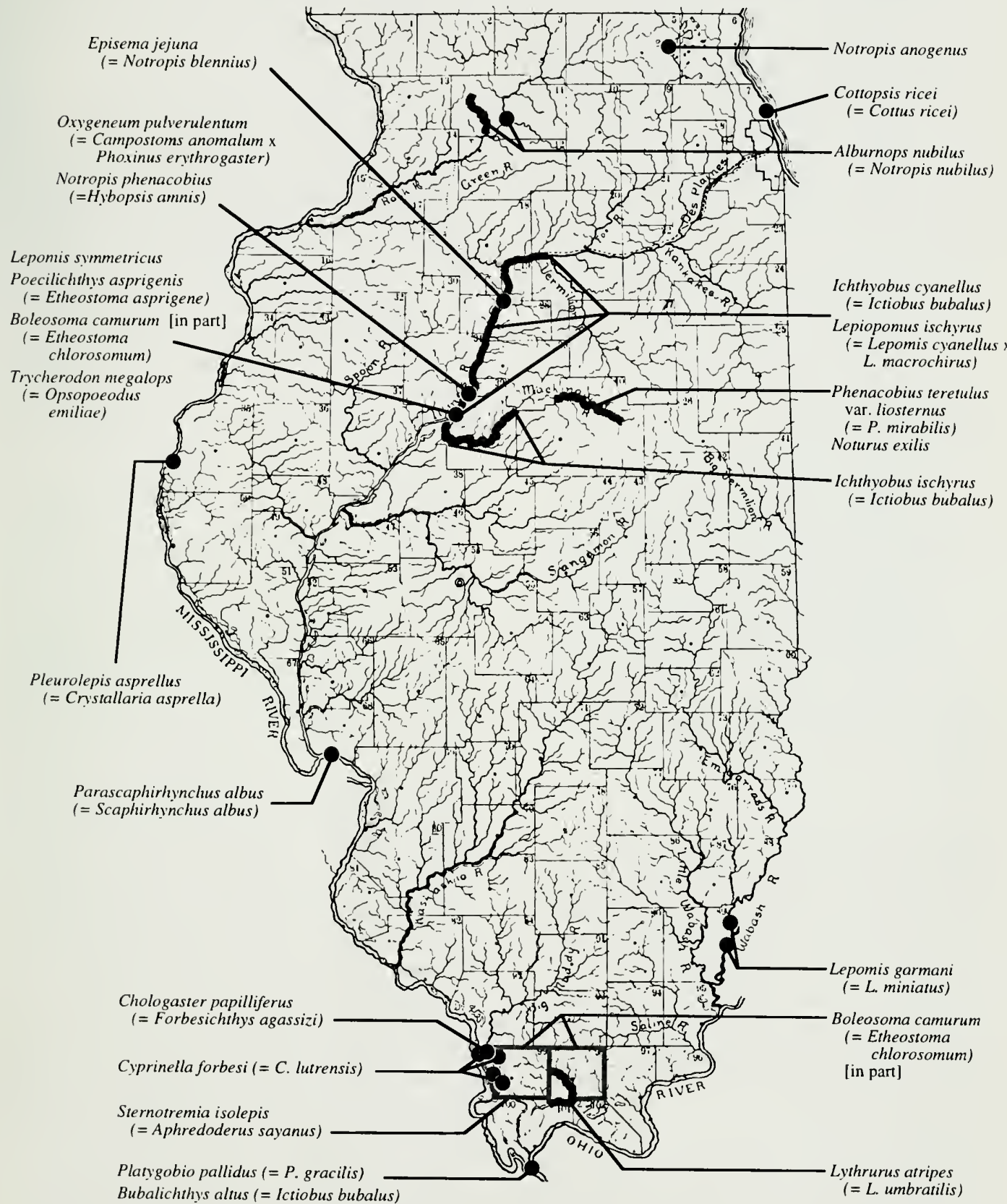


Removed: Specimens previously, but no longer, considered to be types.

Taxonomic status

\section{= Species name recognized Author} year (as cataloged in INHS collection). Current status and summary of taxonomic history of genus and species if species name recognized differs from name appearing in original description. The names currently used in the INHS Fish Collection are based on three sources: A Field Guide to Freshwater Fishes of North America North of Mexico (Page and Burr 1991), Common and Scientific Names of Fishes From the U.S. and Canada (Robins et al. 1991), and The Native Freshwater Fishes of North America (Mayden et al. 1992). Discrepancies in taxonomy with and between the above sources are noted.

Donated Material

Type status

\section{museum acronym and catalog} number of specimens donated from INHS (or ISLNH) to other institutions; (number of specimens, length, sex); locality; collector (field collection number); date; ISLNH accession number or ex. INHS catalog number.

Species name: The specific (or subspecific) epithet is preceded by the genus (or species) in which the taxon was originally described as new.

Author year: Refers to the surname(s) of the author(s) of the taxonomic name and the year of publication of either the original description or the proposal of the taxon as new (as is the case for species described by bibliographic reference). In an original description, the author(s) is(are) generally (but not always) indicated after the taxonomic name at the beginning of the description. If the author(s) is(are) not given, the author(s) of the publication is(are) applied.

Literature citation: Refers to publication in which the taxon is first named and diagnosed as new (see Literature Cited for complete citation). For the most part, this publication includes the original description; however, a species may be proposed as new and described by bibliographic reference to a prior publication (see account for Lepiopornus ischyrus).

Page number: Refers to the page on which the name first appears with the annotation "n. s.", "n. sp.", "new species," or similar expression and is followed directly by either the species" description or a bibliographic reference to the description.

Figures and plates: Refers to plates and figures appearing in the publication that illustrate the taxon described as new. They may be of the holotype, paratype, or non-type material and include photographs and illustrations of entire specimens, external traits (e.g., pigmentation), internal structures (e.g., bones), and subcellular features (e.g., karyotypes). In an original description, figures and plates are generally (but not always or entirely) indicated below the species name before the account of type material and description. Distribution maps, graphs, cladograms, and so on are not cited here although they sometimes are indicated as figures below the species name.

Type status: Type material is broadly categorized into name-bearing types (holotypes, lectotypes, neotypes, and syntypes) and paratypes (includes allotypes, paratopotypes, and paralectotypes). The definitions and proper applications of these terms are specified in the International Code of Zoological Nomenclature (ICZN) (Ride et al. 1985) adopted by the General Assembly of the International Union of Biological Sciences. A brief interpretation of type nomenclature is provided below.

A species (or subspecies) name is physically represented and uniquely identified by a single specimen (= holotype) designated by its original author at the time of publication of the original description (or reference to such). Prior to the widespread adoption of ICZN, a species often was described from a series of specimens (= syntypes) that may or may not correspond to a single locality (= type locality). Any subsequent author (preferably in a revisory work) may designate one specimen from a syntypic series (= lectotype) to become the unique bearer of the species name (guidelines for lectotype designation specified in ICZN). The remaining specimens (former syntypes) become paratypes specifically referred to as paralectotypes. If the holotype (or lectotype) is 
either lost or destroyed, an author may designate another specimen (= neotype) to be the name-bearing type only in connection with a revisory work as specified in ICZN. A neotype also can be designated for a taxon for which no type(s) ever existed. In connection with the original species description, an author may identify any number of specimens (= paratypes) from various localities as specifically (or subspecifically) referable to the holotype specimen. Paratype specimens collected from the type locality are referred to as paratopotypes. An allotype is a paratype of opposite sex to the holotype designated by the author in the original species description. Paratypes have no special standing under ICZN and do not qualify as name-bearing types.

Name-bearing type(s): Information on the name-bearing type(s) is(are) provided for all species represented in the INHS type collection whether or not the name-bearing type(s) is(are) deposited at INHS.

Paratypes: With the exception of allotypes, only paratype material either deposited at INHS or donated from INHS (or ISLNH) to other institutions is listed (see original species description for complete list of paratype material). Information on the allotype (if designated) follows the holotype. Collection data for paratopotypes and allotypes are the same as that given for the holotype unless changes in collector and/or date are specified.

\section{Museum acronym and catalog number:}

Museum acronyms follow Leviton et al. (1985) with the addition "ISLNH" for the Illinois State Laboratory of Natural History and "IU" for the old Indiana University collection. ISLNH numbers refer to entries in an accession catalog which specify either a single specimen or a single collection of various specimens or species from a particular locality. Institutions and catalog numbers not specified for type specimens in the original description are set in brackets. Museum and catalog numbers formerly attributed to specimens are preceded by "ex.".

Length, sex: Appear either as published in the original species description or as determined by subsequent authors (the latter set in brackets). Measurements, for the most part, correspond to standard length (SL) in millimeters as opposed to total length (TL) (Hubbs and Lagler 1947); however, older descriptions often reported lengths in inches without indicating the basis for measurement. Sex and condition (e.g., breeding male) are often provided for namebearing types in the species description.

Locality, collector, and date: Locality and collection data appear largely as published with slight rearrangements to suit the format described above. Locality information is not repeated for paratopotypes and allotypes; collector and date of collection are the same as the holotype unless specified. Any information that does not appear with the original species description but contributes to the identity of the type specimen(s) is given in brackets. Sources of such information include subsequent publications, labels and tags found with the specimens, the ISLNH accession catalog, and the current INHS database. Documentation and explanations of additional information are provided in the "Remarks."

Donated material: Type specimens (usually paratypes) formerly deposited either at IHNS or ISLNH and subsequently donated to other institutions. This list often does not represent all the extant type material, and the original species description should be consulted for a complete list. 


\section{List of Types}

\section{ACIPENSERIDAE}

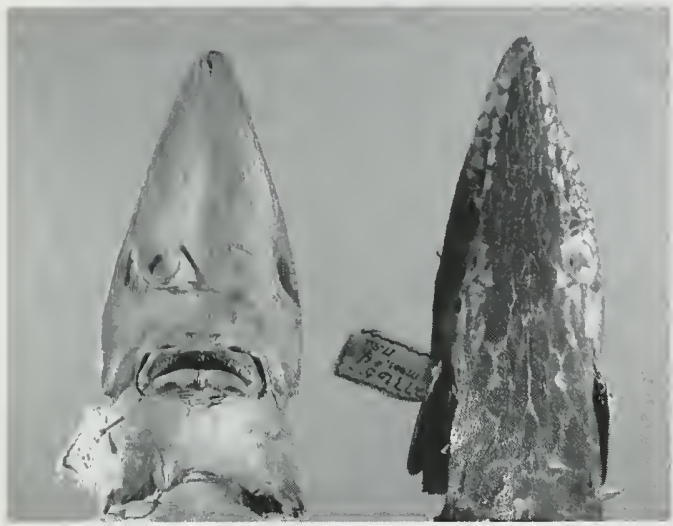

Parascaphirhynchus albus Forbes and Richardson 1905. Syntypes. 1NHS 26944, Mississippi River at or near Grafton, [Jersey County], Illinois (= Scaphirhynchus albus).

Parascaphirhynchus albus Forbes and Richardson 1905.

Forbes and Richardson 1905:38, Pls. 4 (top), 5(1), 6(1), 7(1).

Syntypes

[INHS 26944] ([ 3 entire +2 heads only], 19 to 43 in. to base of caudal fin, all male); Mississippi River at or near Grafton, [Jersey County], Illinois; received from H.L. Ashlock; [18-27 May, 6 July, and 14 October 1904; ISLNH acc. nos. 27765 (3), 27771 (1), and 27773 (1), respectively].

Remarks: Original description based on syntypic series of nine specimens, five of which were recovered by Smith and Bridges (1960:253); the others are listed as missing. Specimens are in very poor condition and stained green from the copper container in which they were originally stored. A photograph of an entire specimen was published with the description; however, it is impossible to determine unequivocally whether the photograph represents one of the extant syntypes.

Missing: Syntypes ISLNH acc. no. 27772 (3), 5 October 1904; and ISLNH acc. no. 27773 ( 1 of 2 ), 14 October
1904. (see Donated Material).

\section{Taxonomic Status}

= Scaphirhynchus albus (Forbes and

Richardson 1905)

On their new species Forbes and

Richardson (1905:38) commented:

"Recognizing...the generic criteria proposed for the scaphirhynchoids by

Berg ('04), we regard this form as generically distinct from species hitherto described." Forbes and Richardson (1905) thereby proposed Parascaphirhynchus as a new genus. According to Bailey and Cross (1954:173), Berg (1911:138, 308-309, and 1948:104) did not support this decision and placed albus in Scaphirhynchus Heckel 1836. Bailey and Cross (1954) agreed and formally synonymized Parascaphirhynchus with Scaphirhynchus. Bailey and Cross also verified the specific distinctness of S. albus, dispelling previous doubts of its validity. Hubbs (1951:14) and Riggs and Moore (1951) pointed out that Scaphirhynchus is neuter and the specific name is properly written as album. Despite such appeals the original spelling (albus) is currently used (Page and Burr 1991; Robins et al. 1991; Mayden et al. 1992).

Donated Material

Bailey and Cross (1954:199) suspected the fish measured by Berg (1911:319) to be from the original syntypic series. A specimen (or specimens?) was sent to him by Forbes and may correspond to one of the missing syntypes listed above. The specimen was presumably deposited in the Zoological Museum of the Academy of Sciences of U.S.S.R., Leningrad [= St. Petersburg]; however, its current status is unknown.

\section{CYPRINIDAE}

Notropis albizonatus Warren and Burr 1994. in Warren, Burr and Grady 1994: 869 ,

Fig. 2.

Holotype

INHS 29588 (56.3 mm SL, breeding male); Little South Fork Cumberland River at ford at Ritner, $20.9 \mathrm{~km} \mathrm{E}$ Monticello, $4.8 \mathrm{~km} \mathrm{~N}$ hwy $92\left(36^{\circ}\right.$ 
$\left.47^{\prime} \mathrm{N}, 84^{\circ} 37^{\prime} \mathrm{W}\right)$, Wayne/McCreary county line, Kentucky; B.M. Burr, D.A. Carney, P.A. Ceas. L.M. Page, and M.L. Warren. Jr.; 24 June 1990. Paratopotypes

INHS $58665(21,45.0-55.2 \mathrm{~mm} \mathrm{SL})$.

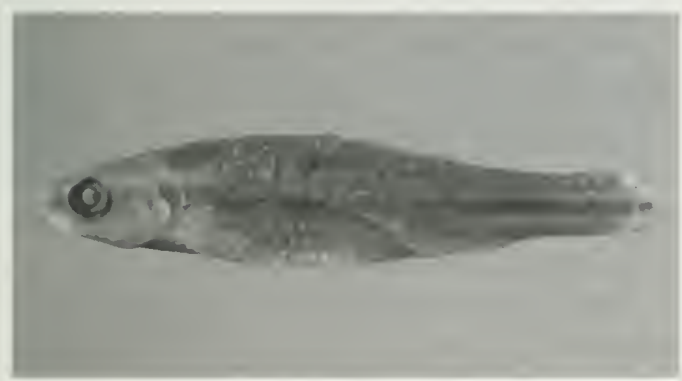

Notropis anogenus Forbes 1885. Lectotype. INHS 26948, Fox River at McHenry, [McHenry County]. Illinois.

Notropis anogenus Forbes 1885.

Forbes 1885:138.

Lectotype

[INHS 26948 (43 mm SL, adult)]; Fox River [lllinois River drainage] at McHenry, [McHenry County], Illinois; [8-10 May 1880; ISLNH acc. no. 50].

Remarks: Original description based on syntypic series of 24 specimens, 8 of which were recovered by Smith and Bridges (1960:253). Bailey (1959:120) designated a lectotype and pointed out that two of the eight specimens in the original syntypic series were Notropis heterodon (Cope 1865). Bailey considered Forbes' original description clearly to be based on individuals of $N$. anogenus. Type specimens are in poor condition (desiccated); measurements determined by Bailey (1959).

Paralectotypes

[INHS 26949 (5, 29-34 mm SL); collection data same as lectotype; ISLNH acc. no. 50].

Donated Material

Paralectotypes

[USNM 64153 (7); collection data same as lectotype; ISLNH acc. no. $50]$.

Remarks: USNM types located by Gilbert (1978:26).
Notropis cahabae Mayden and Kuhajda 1989. Mayden and Kuhajda 1989: 3, Figs. 1a, 2 a. Holotype

UAIC 9119.01 (39.8 mm SL, breeding male); Cahaba River, $7.2 \mathrm{~km}$ NNE Centreville, Sec. 32. T24N, R10E, Bibb County, Alabama; J.M. Pierson and S.G. Puleo; 22 June 1986.

\section{Paratypes}

INHS $65086(3,37.7-42.6 \mathrm{~mm} \mathrm{SL})$; Cahaba River at Co. Rd. 27, [6.5 mi NE Centreville], Sec. 33, T24N, R10E,

Bibb County, Alabama; [R.L. Mayden, et al. (RLM 88-24)]; 20 May 1988; [ex. UAIC 8358.08].

Notropis cardinalis Mayden 1988.

Mayden 1988:156, Fig. la, b.

Holotype

KU 20963 ( 85.7 mm SL, breeding male); Five Mile Creek, south of the Kansas state line, Sec. 22, T29N, R24E, Ottawa County, Oklahoma; R.L. Mayden and F.B. Cross; 9 May 1984. Paratopotypes

INHS 62291 (3, 76.7-84.8 mm SL).

TAXONOMIC Status

= Luxilus cardinalis (Mayden 1988).

According to Gilbert (1964:110),

Rafinesque (1820:47) described the genus Luxilus. Jordan (1885) reclassified Luxilus as a subgenus of Notropis Rafinesque 1818, following Gilbert's (1884:201) proposal that a number of cyprinid species be combined under the name Notropis. Despite early attempts to restore its generic status (Jordan 1929a:82; Jordan et al. 1930:128), Luxilus was considered a subgenus of Notropis by most workers (e.g., Gilbert 1964; Lee et al. 1980; Mayden 1988). Phylogenetic studies of North American minnows by Mayden (1989) and Coburn and Cavender (1992) recognized Luxilus as a distinct genus and prompted widespread acceptance of its generic rank (e.g., Page and Burr 1991; Robins et al. 1991; Mayden et al. 1992). 
Notropis edwardraneyi Suttkus and Clemmer 1968.

Suttkus and Clemmer 1968:19, Figs. 1, 4, 7. Holotype

TU 49485 (57.6 mm SL, adult);

Alabama River at Yellow Jacket Bar,

River Mile 129.8 (U.S. Corps of

Engineers Navigation Chart, 1958), 1.2 miles downriver from Holly Ferry crossing or 12.5 miles east of Pine Hill, Wilcox County, Alabama; R.D. Suttkus and G.E. Gunning (RDS 4097); 8 March 1967 (2245 to 2345 hours).

Paratypes

[INHS 76394] (20); main channel of Alabama River at Watts Bar, $3.5 \mathrm{mi}$. above Cahaba, River Mile 204.5, Dallas County, Alabama; R.D. Suttkus (RDS 3515) [and Environmental Biology Class]; 29 June 1964; ex. TU 33381. Remarks: INHS paratypes removed from TU 33381, the lot designated as paratype material in published account.

Nocomis effusus Lachner and Jenkins 1967. Lachner and Jenkins 1967:560, Figs. 2-4, 5 (top), 6 (top).

Holotype

USNM 231703 (190 mm SL, nuptial male); Cumberland River drainage, Logan County, Kentucky, Whippoorwill Creek at Lickskillet near route 1041 bridge, 8 airmiles SW Russellville; W.M. Clay, B.T. Carter, and Kentucky Department of Fish and Wildlife Resources personnel; 6 May 1955.

Paratypes

INHS [26969] (3, 64-157 mm SL); South Harpeth River (Cumberland River drainage), Rt. 96 bridge 4.2 miles E Fairview, Williamson County, Tennessee; [M.M. Hensley and P.W. Smith]; 23 July 1965.

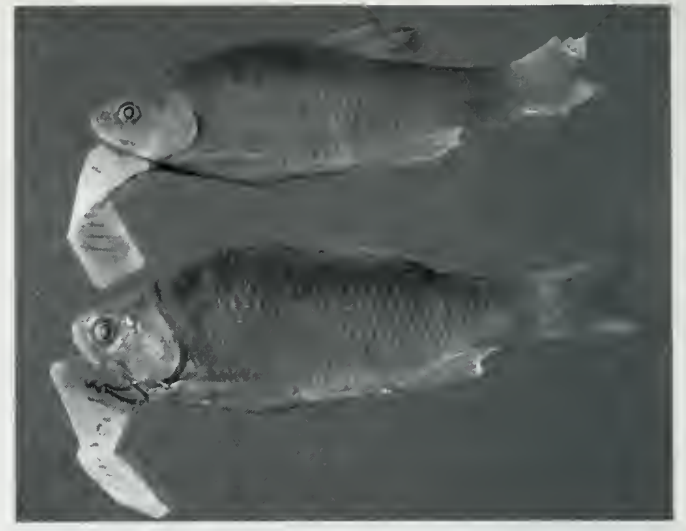

Cyprinella forbesi Jordan 1878. Paralectotypes. INHS 86451, clear streams [= Clear Creek] of southern Illinois [Union County] (= Cyprinella lutrensis).

Cyprinella forbesi Jordan 1878. Jordan 1878a:57.

Lectotype

[USNM 29869 (1, $50.8 \mathrm{~mm} \mathrm{SL})$ ]; clear streams [ $=$ Clear Creek, Mississippi River drainage] of southern Illinois [Union County]; S.A. Forbes; [16 July 1877; ISLNH acc. no. 41].

Remarks: Original description based on a syntypic series of "many specimens." No type was selected in the original description, and Gilbert (1978:43) considered USNM 29869 to be a syntype. However, in the synonymy of Notropis lutrensis (Baird and Girard), Jordan and Evermann (1896:272) list Cyprinella forbesi with the parenthetical annotation "Type, No. 29867 [= 29869]. Coll. Forbes." Böhlke (1953:31) corrected the USNM number "mistakenly" reported by Jordan and Evermann and considered their reference to constitute a lectotype designation. According to ICZN Art. $74 \mathrm{~b}$ (1985:74), this designation can be considered valid.

Gilbert (1978:43) listed the type locality as "Illinois R., Union Co., Illinois" (presumably based on information with the syntypes). The Illinois River neither borders nor passes through Union County (which is in southern Illinois) and is here omitted from the type locality. The USNM lectotype bears ISLNH acc. no. 41 
(Williams 1996). The corresponding ISLNH catalog entry specifies collection date and locality as "Clear Creek, Union Co., Ill," which is apparently synonymous with Jordan's (1878a:58) and Jordan and Evermann's (1896:272) reference to "clear streams in southern Illinois." Measurement according to Gilbert (1978).

Paralectotypes

[INHS 86401 (6, 36.5-48.3 mm SL)]; mud-holes on the bottoms [Union County] Illinois; S.A. Forbes; [July 1877; ISLNH acc. no. 216].

[INHS 86451 (21, 36.0-54.1 mm SL, several tuberculate adults); collection data same as lectotype; ISLNH acc. no. 41 ].

Remarks: Original description cites "Many specimens obtained by Professor Forbes in clear streams of southern Illinois, a few from mud-holes on the bottoms." Twenty-seven specimens in two lots recently found in the INHS collection appear to be of the original syntypic series and are recognized as paralectotypes. The specimens are in fair condition (somewhat desiccated), and many retain part of the original sheen (but none of the color) of Cyprinella lutrensis. INHS 86451 includes several tuberculate adults (tubercle pattern discussed by Jordan in original description). All of the specimens are individually fitted with a tag indicating their ISLNH accession number. The pharyngeal arches of the largest individual $(54.1 \mathrm{~mm}$ SL, INHS 86451 ) have been removed, set in cotton, and returned to the specimen's gill chambers. The type status of INHS 86401 (ISLNH acc. no. 216) is corroborated by its accession catalog entry "mud holes in bottoms, Union Co.", a location repeated in Jordan's original description which presumably refers to the floodplain of the Mississippi River.

TAXONOMic Status

\section{$=$ Cyprinella lutrensis (Baird and}

Girard 1853)

According to Gilbert (1978), Jordan (1885:812) was first to synonymize forbesi with Cyprinella lutrensis. Hubbs (in Hubbs and Ortenburger
1929:75) provisionally recognized forbesi as a northern subspecies of C. lutrensis, but lacked material to delimit its range. Matthews (1987) studied geographic variation in C. lutrensis and showed populations to be relatively homogeneous in Illinois, the upper Mississippi drainage, and northeastern Missouri, differing from those to the west in the Great Plains. Matthews noted that a regional study of transition from Illinois to the Great Plains might reveal a geographically definable subspecies forbesi, but he did not officially diagnose this form. This subspecies is not currently recognized (e.g., Smith 1979; Mayden 1989).

Donated Material

Lectotype

[USNM 29869] (see account above). Paralectotypes

[CAS-SU 1290 (2, 53.2-57.4 mm SL); locality data probably same as INHS 86401/86451]; S.A. Forbes; [summer 1877].

Remarks: Böhlke (1953:31) reported specimens as "lecto-paratypes" collected from Union County, Illinois, in the summer of 1877 (ISLNH acc. no. not indicated). Measurements according to Gilbert (1978).

Notropis hubbsi Bailey and Robison 1978.

Bailey and Robison 1978:3, Pl. 1.

Holotype

UMMZ 197480 (48.1 mm SL, adult pre-spawning male); Locust Bayou, tributary to Ouachita River, I km W Locust Bayou at Arkansas highway 4 bridge, Calhoun County, Arkansas; S. Pelt and J. Stephen (SP 75-27); 10 May 1975.

Paratypes

INHS 18147 (50.5 mm SL); Wolf Lake [Mississippi River drainage], Union County, Illinois [T11S, R3W, Sec. 28]; B.M. Burr and L.M. Page; 21 June 1973.

Remarks: Twenty-five additional specimens were collected with this paratype; however, their deposition is unknown.

INHS 18152 (2, 50, 50 mm SL); 
locality data same as INHS 18147 ;

B.M. Burr, P.W. Smith, and L.M. Page; 25 July 1973.

Remarks: Twenty-one additional specimens were collected with these paratypes and vouchered separately as nontypes (INHS 37648).

INHS 18157 (1, $34 \mathrm{~mm} \mathrm{SL);} \mathrm{locality}$ data same as INHS 18147; B.M. Burr, L.M. Page, and J.A. Boyd; 29 November 1973.

INHS 75026 (3, 32-33 mm SL); locality data same as INHS 18147; B.M. Burr, L.M. Page, and J.A. Boyd; 24 January 1974.

INHS 75027 (2, 37-39 mm SL); locality data same as INHS 18147; B.M. Burr, J.A. Boyd, and L.R. Davis; 28 February 1974.

INHS 75028 (2, 37-39 mm SL); locality data same as INHS 18147;

B.M. Burr, J.A. Boyd, and L.R. Davis; 28 March 1974.

Taxonomic Status

= Pteronotropis hubbsi (Bailey and Robison)

Fowler (1941:234) proposed

Pteronotropis as a subgenus of Notropis Rafinesque 1818. Mayden (1989) and Mayden et al. (1992) recognized Pteronotropis as a distinct genus composed of four species, but did not include hubbsi. Page and Burr (1991) accepted the generic status of Pteronotropis and referred hubbsi to this genus. Robins et al. (1991) did not recognize the generic rank of Pteronotropis.

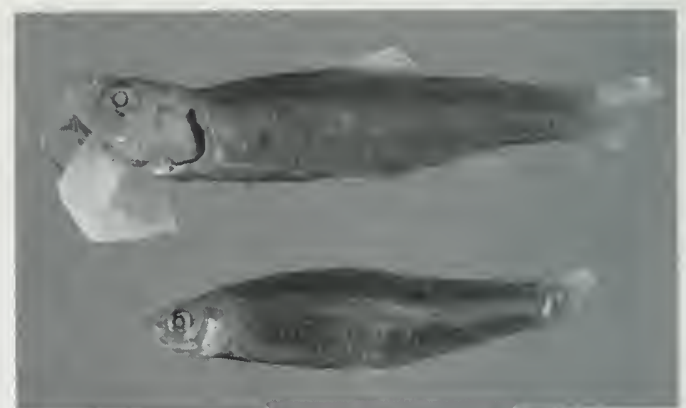

Episema jejuna Forbes 1878. Syntypes. INHS 26947, Illinois River [at Henry, Marshall County]. Illinois (= Notropis blennius).

Episema jejuna Forbes 1878.

in Jordan 1878a:60.

Syntypes

[INHS 26947 (18, 31.8-58.6 mm SL)];

Illinois River, [at Henry, Marshall

County], Illinois; [1 November 1877;

ISLNH acc. no. 243].

Remarks: Original description based on syntypic series of an unknown number of specimens. Smith and Bridges (1960:253) recovered a collection of 17 type specimens (misreported as 16) to which another ( $55.8 \mathrm{~mm} \mathrm{SL}$ ) is here added. Range of SL measurements are from Gilbert (1978:51).

Removed: Smith and Bridges (1960) suggested that two specimens (INHS 26946) from the Illinois River, at Pekin. Tazewell County, Illinois, might be "types"; however, one of the two bears a tag indicating ISLNH accession number 226, which corresponds to 2 June 1880 as the date of collection. As Smith and Bridges (1960) noted, this date is subsequent to that of the original description (Forbes 1878). Because there is currently no evidence to substantiate the type status of these specimens, they are herein removed from the syntypic series.

Taxonomic Status = Notropis blennius (Girard 1856) Forbes' species description was followed by Jordan's (1878a:61) recommendation that Episema Cope and Jordan in Jordan (1877a) be restored to generic rank. Jordan and Evermann (1896:254) later synony- 
mized Episema with Notropis

Rafinesque 1818 and noted that the name was preoccupied (Episema Ochsenheimer 1816, a genus of lepidopteran insect according to Gilbert 1978:15). Hubbs (1926:43) subsequently synonymized Notropis jejuna with $N$. blennius (Girard 1856). Hubbs and Bonham (1951:104) and Hubbs and Lagler (1958:82) retained $N$. b. jejunus as a valid subspecies; however, this was not substantiated by Suttkus and Clemmer (1968) and the subspecies name has since fallen from use (e.g.. Gilbert 1978; Smith 1979).

DONATEd Material

Syntypes

[CAS-SU 1278 (3, 54.0-60.2); (label in jar says "Illinois River, Illinois"); ISLNH acc. no. 243?].

[CAS 29302 ex. old IU $4725(2,51.8-$ 54.0); (label in jar says simply "Illinois”); ISLNH acc. no. 243?].

Remarks: Information on CAS specimens is from Gilbert (1978:51); specimens are presumed to be of the syntypic series originally accessioned as ISLNH 243.

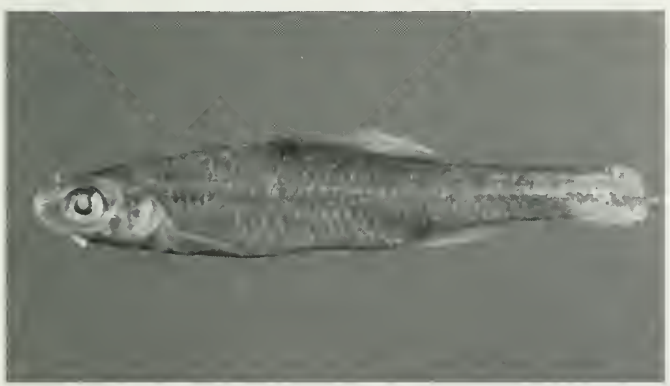

Trycherodon megalops Forbes 1883. Paralectotype. INHS 26956, Illinois River [Long Lake] at Pekin, [Tazewell County, Illinois] (= Opsopoeodus emiliae emiliae).

Trycherodon megalops Forbes 1883. in Jordan and Gilbert 1883:247.

\section{Lectotype}

[USNM 28406 (40.4 mm SL)]; Illinois River [Long Lake] at Pekin, [Tazewell County, Illinois; S.A. Forbes; 27 October 1879; ISLNH acc. no. 180].

Remarks: Original description of genus and species based on syntypic series of "several" specimens from three different localities; length of largest specimen given as $21 / 5$ inches. Gilbert and Bailey (1972:21) designated the lectotype, thereby restricting the type locality to Illinois River, Long Lake, at Pekin.

Paralectotypes

The following specimens were recovered after Smith and Bridges' (1960) publication and apparently overlooked by Gilbert and Bailey (1972) and Gilbert (1978). They are herein recognized as paralectotypes.

[INHS 26956 (13, 36.5-42.1 $\mathrm{mm}$ SL); collection data same as lectotype; ISLNH acc. no. 180].

Remarks: Specimens in fair to poor condition, somewhat desiccated. The jar bears an original label with the information "Trycherodon megalops Forbes, Long L., Pekin, Ill., Oct. 27 , 1879." Two sets of pharyngeal arches are placed in separate glass vials. Five individuals are fitted with tags bearing their ISLNH accession number.

[INHS 26957 ( 1, 40.9 mm SL)]; Illinois River [Peoria Lake] at Peoria, [Peoria County, Illinois; H. Garman; 26-29 June 1878 or 1879 ; ISLNH acc. no. 26359].

Remarks: Specimen in poor condition, desiccated; head nearly detached.

[INHS 26958 (4, 30.6-36.9 mm SL)]; Mackinaw Creek [= River, Illinois River drainage, plotted $4.5 \mathrm{~km} \mathrm{NE}$ Congerville in Forbes and Richardson 1909: map XXX, Woodford County, Illinois; 9 April 1880; ISLNH acc. no. 27558].

Remarks: Specimens in poor condition, desiccated; one set of pharyngeal arches placed in a separate glass vial.

Taxonomic Status

= Opsopoeodus emiliae emiliae Hay 1881

According to Gilbert (1978:61), Jordan (1885:821) was first to synonymize Trycherodon megalops Forbes 1883 with Opsopoeodus emiliae Hay 1881. Schrenkeisen (1938:107) subsequently regarded it as a northern subspecies $O$. e. megalops. Hubbs and Lagler 
(1947:64) recognized the northern subspecies megalops and applied the name $O$. e. emiliae to the form from Mississippi to Florida. Gilbert and Bailey (1972) described a new subspecies, O. e. peninsularis, from peninsular Florida, but did not recognize subspecific differences between populations in Illinois and Mississippi and relegated megalops to the synonymy of Opsopoeodus emiliae emiliae (nominate species originally described from Mississippi). Furthermore, Gilbert and Bailey interpreted emiliae as a specialized derivitive of Notropis Rafinesque 1818 and downgraded Opsopoeodus to subgeneric status. Campos and Hubbs (1973) presented karyotypic evidence to re-establish the generic distinctive ness of Opsopoeodus. Their findings were corroborated later by osteology (Coburn and Cavender 1992) and reproductive behavior (Page and Johnston 1990). The generic status of Opsopoedus was subsequently accepted by Page and Burr (1991), Robins et al. (1991) and Mayden et al. (1992).

DONATED MATERIAL

Lectotype

[USNM 28406] (see account above). Paralectotype

[CAS $13513(1,35 \mathrm{~mm} \mathrm{SL})$ ]; collection data same as INHS 26957; ISLNH acc. no. 26359].

Remarks: Gilbert and Bailey (1972:21) recognized this specimen as a paratype (= paralectotype) and cited locality as "Long River, Peoria, Illinois." "Long River" presumably refers to the Illinois River at Peoria (also called Peoria Lake), not Long Lake at Pekin (the type locality).

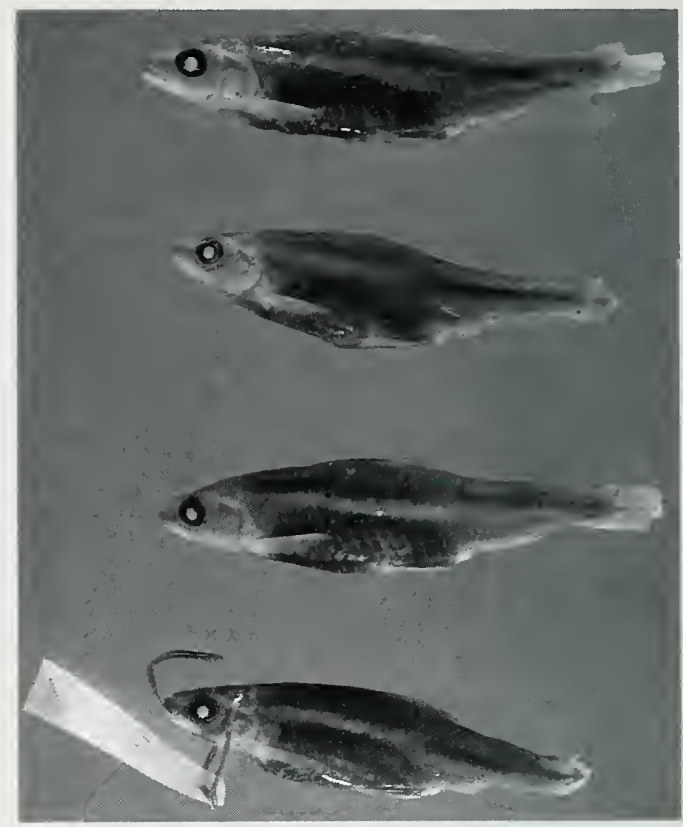

Alburnops nubilus Forbes 1878. Syntypes. INHS 26945, Rock River [at Oregon], Ogle County, Illinois (= Notropis nubilus).

Alburnops nubilus Forbes 1878. in Jordan 1878a:56.

Syntypes

[INHS 26945 (6, 46.6-55.3 mm SL)]; Rock River [Mississippi River drainage, at Oregon] Ogle County, Illinois; [5 June 1877; ISLNH acc. no. 28266]. Remarks: Original description based on syntypic series of 20 specimens; length given as " $21 / 4$ inches to the caudal" (Jordan 1878a:56). Smith and Bridges (1960:253) recovered a lot of six specimens recorded in the ISLNH accession catalog as "types of Hybognathus nubila, Forbes." The specimens are in poor condition and one bears a tag with date barely readable as 1877 . Measurements are from Gilbert (1978:65). Date of collection (6 May 1877) given by Gilbert (1978:65) based on erroneous label placed with specimens.

[INHS 86034 (1, $45.8 \mathrm{~mm}$ SL)]; Rock River [Pine Creek], Ogle County, Illinois; [E.W. Nelson; 15 July 1877 ; ISLNH acc. no. 1426].

Remarks: This specimen was presumably available to Forbes for the original 
description and is here added to the syntypic series. The specimen is in poor condition and bears a tag with accession number corresponding to the entry "Rock River, Ogle County, 15 July 1877." Also placed with the specimen is an original label with the pencil notation "Hybopsis fraetensis, Pine Cr., Ogle Co.," the species it was mistakenly identified as by Nelson (1876:47) and possibly Jordan (1878a:57).

TAXONOMIC Status = Notropis nubilus (Forbes 1878)

The species mubilus was long assigned to the genus Dionda Girard 1856 (Jordan et al. 1930; Smith 1979) on the basis of its elongate intestine. Swift (1970) transferred nubilus to the genus Notropis Rafinesque 1820, a placement that gained acceptance as additional studies questioned the taxonomic significance of gut morphology (e.g., Snelson 1971; Hubbs and Miller 1977). Notropis nubilus was adopted by Page and Burr (1991), Robins et al. (1991), and Mayden et al. (1992).

\section{DONATED MATERIAL}

[CAS-SU 1280 (3); Kishwaukee River (Rock River drainage), at Belvidere, Boone County, Illinois; S.A. Forbes; summer of 1877].

Removed: Böhlke (1953:30) listed the specimens above as "Lecto-paratypes." Gilbert (1978:65) noted that the locality (Belvidere, Illinois) was not included in Forbes' original description (this site was listed as a collecting locality in Forbes 1884:60). Although the specimens are from the Rock River drainage and were almost certainly identified by S.A. Forbes, their collection locality (Boone County) was not mentioned in the original description and they are not considered valid paralectotypes.

[USNM 28410 (?); Kishwaukee River, Illinois; 1880].

Removed: In their synonymy of Hybognathus nubila (Forbes), Jordan and Evermann (1896:215) refer to USNM material of $A$. nubilus as "Type, No. 28410. Coll. Forbes." However, there is no record of USNM 28410 or type material of $A$. nubilus currently at USNM (Williams 1996). Gilbert (unpublished) lists Jordan and Evermann's (1896:215) "type" as specimens collected in 1880 from the Kishwaukee River, Illinois. Because the USNM material appears to have been collected from outside the type locality after the published species description, they are not considered valid types.

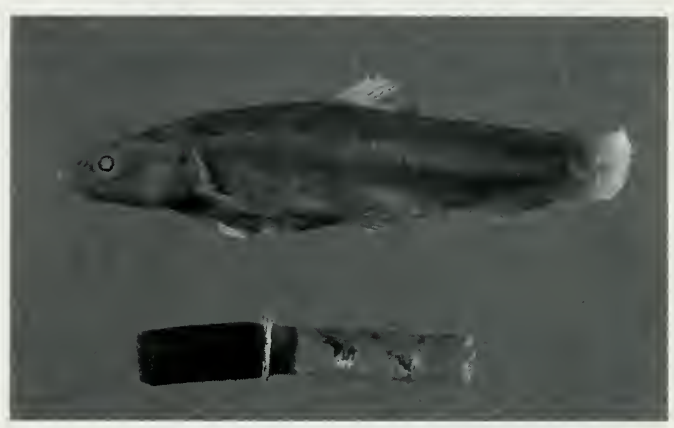

Platygobio pallidus Forbes 1883. Holotype. INHS 26951, Ohio River at Cairo, [Alexander County, Illinois] (= Platygobio gracilis gracilis). Pharyngeal arches shown in glass vial.

Platygobio pallidus Forbes 1883. in Jordan and Gilbert 1883:220. Holotype

[INHS 26951] (L. 2.5 inches); Ohio River [Mississippi River drainage], at Cairo, [Alexander County, Illinois; 23 September 1879; ISLNH acc. no. 26403].

Remarks: Original description based on "one specimen from the Ohio River at Cairo" (holotype by monotypy).

Smith and Bridges (1960:253) recovered a specimen considered to be the holotype despite some inconsistency with the original description. The specimen is in poor condition (desiccated) but clearly recognizable as Platygobio gracilis. It measures 47.2 mm (1.86 in.) SL compared to "L. 2 1/2 inches" given in the original description. Although the caudal fin is missing, the specimen's present total length would appear to be significantly 
less than 2.5 inches. Present counts of fin rays are at odds: 9 dorsal rays (compared to 8 reported), and 9 anal rays ( 8 reported). However, there are about 55 scales in the lateral line as reported. The coelomic cavity is cut open and the pharyngeal arches are removed and placed in a separate glass vial. The pharyngeal teeth are as Forbes described, "stout, 2,4-4,2, hooked," although two teeth (one in each row) are missing from one of the arches. The specimen bears minute tubercles scattered over the dorsal surface of the head and snout, which is consistent with Forbes' mention of "snout tuberculate." Two labels accompany the specimen, one with the ink notation "Platygobio pallidus Forbes," and the other specifying Jordan and Evermann's (1896:326) number for the species $P$. pallidus (544). Its corresponding accession catalog entry reads "Ohio River, Cairo, Ill., Sept. 23, 1879 Platygobio pallidus Forbes." Further evidence of its holotype status is provided by Forbes' (1884:75) statement: "A single specimen of this very rare species $[P$. pallidus], obtained in the Ohio River at Cairo, is the only one hitherto taken."

Taxonomic Status

\section{= Platygobio gracilis gracilis}

(Richardson 1836)

Jordan and Evermann (1896:326) recognized Platygobio pallidus, but considered the species doubtful and perhaps based on the young of $P$. gracilis (Richardson 1836). Forbes and Richardson (1909:17 I) Iater concurred and referred pallidus to $P$. gracilis. Bailey (1951:192) placed Platygobio (and several other "chub" genera) in the genus Hybopsis (Agassiz 1854). Olund and Cross (1961) studied geographic variation in $H$. gracilis and recognized two subspecies, $H . g$. gracilis and $H . g$. gulonella (Cope 1865), placing pallidus in synonymy with the nominate form. Until recently, Hybopsis gracilis was largely recognized (e.g., Smith 1979; Lee et al. 1980 et seq.) despite McPhail and Lindsey's (1970:239) proposed reelevation of Platygobio. Systematic studies of North American minnows by Mayden (1989) and Coburn and Cavender (1992) returned gracilis to the monotypic genus Platygobio. The generic status of Platygobio was subsequently accepted by Page and Burr (1991), Robins et al. (1991), and Mayden et al. (1992).

\section{Campostoma pauciradii Burr and Cashner} 1983.

Burr and Cashner 1983:105, Figs. 1a, b, 2a. Holotype

TU 117030 (106 mm SL, tuberculate adult male); AItamaha (Oconee) River Drainage. Georgia, Hall County, Candler Creek, $1.8 \mathrm{~km} \mathrm{~W} \mathrm{Gillsville} \mathrm{on}$ Hwy. 52; R.D. Suttkus, D.C. Scott, F. Meyers, and S. Larson (RDS 7314); 24 April 1980.

Paratypes

INHS 75130 (5); Apalachicola River Drainage. Georgia, Habersham Co., Soque R. [7 mi. NNW Clarkesville; B.M. Burr, L.M. Page, and D.G. Buth; 11 June 1976].

Remarks: Ten specimens removed from INHS 75130 and cataloged separately as nontypes (INHS 38848).

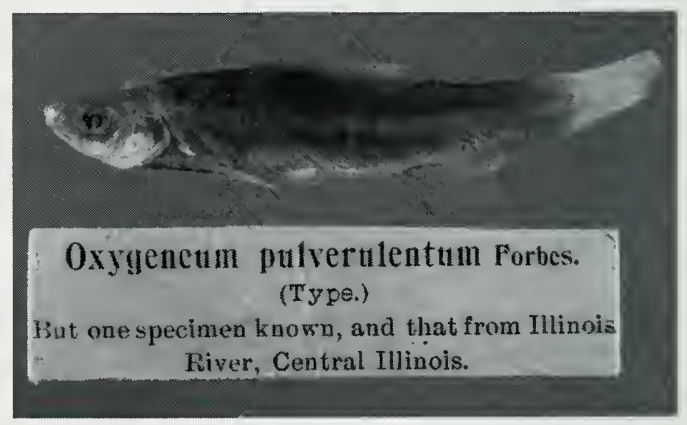

Oxygeneum pulverulentum Forbes 1885. Holotype. INHS 26950, Illinois River at Peoria, [Peoria County], Illinois (= Campostoma anomalum pullum $\mathrm{x}$ Ploxinus erythrogaster).

Oxygeneum pulverulentum Forbes I 885.

Forbes 1885:136.

Holotype

[INHS 26950] (2.5 in long); lllinois River at Peoria, [Peoria County], lllinois; [June] 1878; [ISLNH acc. no. 28378]. 
Remarks: Original description based on one specimen considered the holotype by monotypy. Smith and Bridges (1960:253) recovered the holotype in fair condition (somewhat desiccated).

Taxonomic Status

\section{= Campostoma anomalum pullum}

(Agassiz 1854) x Phoxinus erythrogaster (Rafinesque 1820)

According to Hubbs and Bailey (1952:143), Oxygeneum pulverulentum was recognized by Jordan and Evermann (1896:207) and in various checklists and manuals until Large (1903:14) suggested that the name might have been based on a hybrid. Hubbs and Bailey (1952:143) identified the INHS holotype as the intergeneric hybrid Campostoma anomalum pullum $\mathrm{x}$ Chrosomus erythrogaster.

Chrosomus was referred, as a subgenus, to Phoxinus by Bănărescu (1964) with little comment (both names date from Rafinesque 1820 , and as first reviser Bănărescu selected Phoxinus).

Notropis rupestris Page 1987.

in Page and Beckham 1987:659, Figs. 1

(bottom), 2 (bottom), 3 (bottom), 4 .

Holotype

INHS 61875 (44.3 $\mathrm{mm}$ SL, male); West Fork Stones River at bridge on Rock Springs Road, 2 km E Rock Springs (ca. $18 \mathrm{~km} \mathrm{SSE}$ Murfreesboro), Rutherford County, Tennessee; L.M. Page and C.W. Ronto; 26 May 1986.

Paratopotypes

INHS $61876(81,32-52 \mathrm{~mm} \mathrm{SL})$. INHS 69140 ([164], 28-48 mm SL); L.M. Page and D.A. Carney; 18 October 1985.

Remarks: Number of specimens in INHS 69140 mistakenly published as 158 from an original collection of 278 specimens. Original collection was of 284 specimens: 164 were vouchered as INHS 69140 and the remaining 120 were donated as paratypes.

Donated Material

Paratopotypes

KU 21402 (20, 28-45 mm SL), SIUC $12976(20,29-49 \mathrm{~mm}$ SL), UF 44278
(20, 31 -46 mm SL), UMMZ 213499

(20, 32-46 mm SL), USNM 278490

$(20,31-41 \mathrm{~mm} \mathrm{SL})$ and UT $\mathbf{4 4 . 3 4 6 0}$

(20, 30-42 mm SL); all ex. INHS 69140 .

\section{CHARACIDAE}

\section{Creagrutus melasma Vari, Harold and}

Taphorn 1994.

Vari, Harold, and Taphorn 1994:91, Fig. 1.

Holotype

MBUCV V-22198 (32.4 mm SL);

Venezuela, Estado Guarico, Parque

Nacional Guatopo, Río Orituco, first

bridge along road from Santa Teresa to

Altagracia; H. Moreno and A.

Machado-Allison; 20 May 1992.

Paratypes

INHS $60021(10,33.2-36.0 \mathrm{~mm}$ SL);

Lago de Valencia basin, Río Las

Penitas, Vigirima, Estado Carabobo, Venezuela $\left(\sim 10^{\circ} 20^{\prime} \mathrm{N}, 67^{\circ} 52^{\prime} \mathrm{W}\right)$; D.

C. Taphorn, [L.M. Page, P.A. Ceas, and M.E. Retzer]; 29 [December] 1990.

Remarks: Collection date published incorrectly as 29 November 1990 in account of type material (Vari et al. 1994:91).

\section{ICTALURIDAE}

Noturus albater Taylor 1969.

Taylor 1969:144, frontispiece, Pl. 4 (Fig. 4),

Pl. 11 (Fig. 2).

Holotype

UMMZ 151171; White River, at

Forsyth, on Hwy. M80, Taney County,

Missouri; G.V. Harry and M. Pellock;

4 August 1940.

Paratypes

INHS [26970] (3); Black River [White River drainage], Lesterville, Reynolds County, Missouri; E.M. Lowry; 12-15 October 1948. 


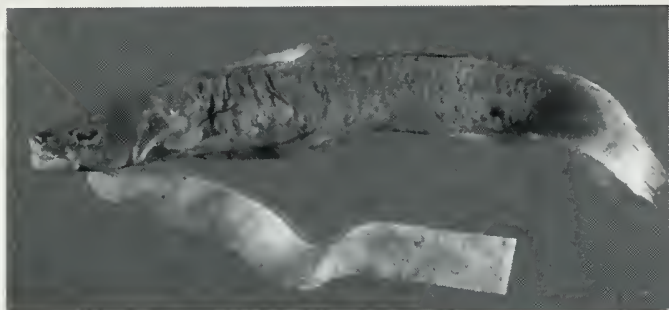

Noturus exilis Nelson 1876. Lectotype. INHS 37651, [Mackinaw River], McLean County, Illinois.

Noturus exilis Nelson 1876.

Nelson 1876:51.

Lectotype

[INHS 37651 (78.4 mm SL)]; [Mackinaw River, Illinois River drainage] McLean County, Illinois; S.A. Forbes; [ISLNH acc. no. 26407].

Remarks: Original description based on syntypic series of three specimens, one of which was recently found in the INHS collection and is herein designated the lectotype (the other two specimens have not been located and are presumed lost). The specimen was incompletely preserved and is in poor condition. It bares a tag with the ink notation "N. exilis, Ill. R." and is referred to in the ISLNH accession catalog as "Noturus exilis, type, Illinois River" (no date given). Forbes and Richardson (1909:199) considered this species to be described "from specimens found in the Illinois River." However, Nelson's original description cited specimens from McLean County, which places the type locality in the Mackinaw River (locality listed on pg. 33 of Nelson 1876). Because McLean County neither includes nor borders the Illinois River proper, references to "Illinois River" are assumed to indicate the drainage rather than the precise collecting locality. During his revision of Noturus, Taylor (1969:62) did not locate any type material of $N$. exilis and proposed that the specimens were destroyed in the Indiana University fire of 1883 (types of other species described by Nelson were located at IU, e.g., Etheostoma phoxocephalum). He did not designate a neotype and considered the probable type locality to be Mackinaw Creek (= River).

Noturus stanauli Etnier and Jenkins 1980. Etnier and Jenkins 1980:19, Figs. 1, 2. Holotype

TU 110929 (36.2 mm SL); Clinch River at Frost Ford, Clinch River Mile 181.1, 11.8 air km WSW of Kyles Ford, Hancock County, Tennessee; D.L. Batch, B.H. Bauer, B.A. Branson, R.T. Bryant, D.A. Etnier, J.L. Harris, J.A. Louton, M.G. Ryon; 21 April 1978.

Paratopotype

INHS 83899 (1); [D.A. Etnier, J.L. Harris, and Ichthyological Class]; 24 October 1978.

\section{LORICARIIDAE}

Aphanotorulus ammophilus Armbruster and Page 1996.

Armbruster and Page 1996:385, Figs. 2,

$3 c, 4$.

Holotype

INHS 32035 (86.0 mm SL); Venezuela, Estado Cojedes, Río San Carlos, Río Portuguesa drainage, at Caño Hondo, $2 \mathrm{~km}$ west of Las Vegas on road from Las Vegas to Campo

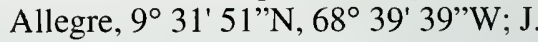
Armbruster, M. Sabaj, K. Cummings, and C. Mayer; 14 January 1994.

Paratopotypes

INHS 34784 (31, 18.3-38.8 mm SL, juveniles).

INHS 34738 (2, 89.4-102.2 mm SL); J. Armbruster, P. Ceas, K. Cummings, C. Mayer; 28 January 1995.

Paratypes

INHS 29001 ( 1 cleared and stained, $69.7 \mathrm{~mm} \mathrm{SL}$ ); Venezuela, Estado Cojedes, Río San Carlos, Río

Portuguesa drainage, WNW Las Vegas, $9^{\circ} 33^{\prime} 40^{\prime \prime} \mathrm{N}, 68^{\circ} 38^{\prime} 89^{\prime \prime} \mathrm{W}$; D.

Taphorn, L. Page, K. Cummings, C.

Mayer, P. Ceas, J. Armbruster, and M. Sabaj; 9 January 1993.

Donated Material

Paratopotypes

ANSP $173089(2,66.9-72.4 \mathrm{~mm}$ SL), and TU 173803 (3, 27.9-40.5 mm SL, 
juveniles); ex. INHS 34784 .

MBUCV V-26460 (1, $89.5 \mathrm{~mm}$ SL), SIUC 23936 (1, $90.6 \mathrm{~mm}$ SL), UAIC $11126.01(1,92.8 \mathrm{~mm} \mathrm{SL})$, and USNM 335171 (2, 41.4-96.1 $\mathrm{mm} \mathrm{SL})$; all ex. INHS 34738 .

Paratypes

FMNH 105064 (2, 66.5-93.6 mm SL), and MCNG $27678(2,65.8-79.8 \mathrm{~mm}$ SL); ex. INHS 29001.

Farlowella colombiensis Retzer and Page 1997.

Retzer and Page 1997:62, Fig. 33.

Holotype

CAS 123733 (132.7 mm SL, male);

Colombia, Meta Department, area of Guaicaramo, Río Upia drainage; A. Maria; January, 1928.

Paratopotypes

INHS $32939(2,134.0-153.9 \mathrm{~mm}$ SL, males); N. Maria; 1932; ex. ANSP 88080.

Farlowella hahni Meinken 1937.

Meinken 1937:77, Fig. 2.

Syntypes

Isbrücker (1980:98) listed two syntypes (158 $\mathrm{mm} \mathrm{SL}$ ) from the type locality "mittleren Paranàgebiete"; the specimens were destroyed in World War II (Isbrücker 1979).

Neotype

UMMZ 228132 (201.0 mm SL, male);

Paraguay, Misiones Department, Río Paraná, approximately $2 \mathrm{~km}$ E. Ayolas, $27^{\circ} 24^{\prime}$ S, $56^{\circ} 46^{\prime}$ W; J. Taylor, T.

Grimshaw, G. Smith, B. Smith, and G. Creighton; 25-26 August 1979.

Remarks: Neotype designated in Retzer and Page (1997:76, Fig. 51).

Paraneotypes

INHS 32942 (2, 111.1-167.8 mm SL); collection data same as neotype; ex. UMMZ 207469.

Farlowella isbruckeri Retzer and Page 1997. Retzer and Page 1997:55, Fig. 24.

Holotype

MZUSP 37641 (131.1 mm SL, male); Brazil, Mato Grosso State, small river on highway from Cuiabá to Porto Velho, approximately $32 \mathrm{~km}$ from
Lacerda; J.C. Garavello; 23 September10 October 1984.

Paratopotype

INHS 32943 ( $1,122.3 \mathrm{~mm} \mathrm{SL})$; ex. MZUSP 37641.

Farlowella paraguayensis Retzer and Page 1997.

Retzer and Page 1997:78, Fig. 54.

Holotype

UMMZ 228129 (143.1 mm SL, male);

Paraguay, Canendiyu Department,

Arroyo Carimbatay, $15.6 \mathrm{~km}$ WSW

Curuguaty, $24^{\circ} 31^{\prime} 06^{\prime \prime} \mathrm{S}, 56^{\circ} 43^{\prime} 30^{\prime \prime}$

W; R. Bailey, J. Taylor, T. Grimshaw,

G. Myers, and G. Creighton; 6 July

1979.

Paratopotypes

INHS 32941 (2, 129.8-133.9 mm SL); collection data same as holotype; ex.

UMMZ 206291.

Farlowella platorynchus Retzer and Page 1997.

Retzer and Page 1997:71, Fig. 44.

Holotype

MHNG 2389.57 (179.0 mm SL, male); Peru, Ucayali Department, Pucallpa, Yarinachocha, Río Ucayali drainage, $8^{\circ}$ 23' S, 74 32' W; H. Ortega; 11 September 1986.

Paratypes

INHS 32940 (2, 89.3-101.3 mm SL);

Peru, Loreto Department, Yarinacocha, creek, $8^{\circ} 16^{\prime} \mathrm{S}, 74^{\circ} 36^{\prime} \mathrm{W}$; R. Vari, H. Ortega, and A. Gerberich; 26 August 1986; ex. USNM 284840.

Farlowella taphorni Retzer and Page 1997. Retzer and Page 1997:51, Fig. 19.

Holotype

INHS 60352 (135.3 mm SL, male); Venezuela, Merida State, Río Muyapas, (Río Torondoy-Lago Maracaibo drainage), $4.5 \mathrm{~km} \mathrm{~S}$ Nueva Bolivia on Hwy 1; D.C. Taphorn, M.E. Retzer, L.M. Page, and P.A. Ceas; 6 January 1991.

Paratopotypes

INHS 32938 (16, 36.0-111.4 mm SL); ex. INHS 60352.

DONATED MATERIAL

Paratopotypes

CAS 81628 (2, 101.3-117.3 mm SL), 
MBUCV-V-24820 (2, 90.9-94.7 mm SL), UMMZ $228130(2,82.3-98.2 \mathrm{~mm}$ SL), USNM $330245(2,94.5-121.1 \mathrm{~mm}$ SL); all ex. INHS 60352.

Chaetostoma yurubiense Ceas and Page 1996. Ceas and Page 1996:672, Fig. 2 (top). Holotype

INHS 34942 (51.2 mm SL); Río

Mayorica (Río Yaracuy system) at Hwy $3,9 \mathrm{~km} \mathrm{~N}$ Albarico near the town of Mayorica, State of Lara, Venezuela $\left(10^{\circ} 25^{\prime} 43^{\prime \prime} \mathrm{N}, 68^{\circ} 40^{\prime} 47^{\prime \prime} \mathrm{W}\right)$; P.A. Ceas, D.C. Taphorn, L.M. Page, K.S. Cummings, C.A. Mayer, J.W.

Armbruster, C.A. Laird, and M.H. Sabaj; 7 January 1993.

Paratopotype

INHS 28872 (1, $49.8 \mathrm{~mm} \mathrm{SL})$.

DONATEd Material

Paratopotypes

MBUCV V-26455 (1, $47.0 \mathrm{~mm} \mathrm{SL),}$ SIUC 24088 (1, $44.6 \mathrm{~mm} \mathrm{SL})$, TU $173801(1,41.9 \mathrm{~mm} \mathrm{SL})$, and UAIC 11131.01 (1, $46.4 \mathrm{~mm} \mathrm{SL})$; all ex. INHS 28872.

Paratypes

USNM 336693 (1, $49.5 \mathrm{~mm}$ SL); Río Capa (Río Urama system), town of Canoabo, State of Carabobo, Venezuela $\left(10^{\circ} 18^{\prime} \mathrm{N}, 68^{\circ} 17^{\prime} \mathrm{W}\right)$; P.A. Ceas, L.M. Page, D.C. Taphorn, and M.E. Retzer; 30 December 1990; ex. INHS 59992.

\section{APHREDODERIDAE}

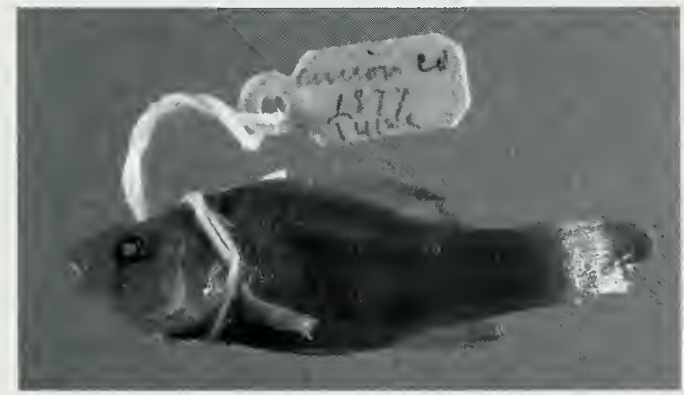

Sternotremia isolepis Nelson 1876. Lectotype. INHS 26952, small streams [possibly Callahan and Drury Creeks, Union County] in South Illinois (= Aphredoderus sayanus gibbosus).

Sternotremia isolepis Nelson 1876.

Nelson 1876:39.
Lectotype

[INHS 26952 (42.8 mm SL)]; small streams [possibly Callahan and Drury Creeks, Union County] in southern Illinois; [S.A. Forbes; ca. 1876; ISLNH acc. no. 26373].

Remarks: Original description based on a "dozen or more" specimens from a "small, weedy tributary to the Calumet river near Chicago, and small streams in South Illinois." Smith and Bridges (1960:253) recovered three syntypic specimens in fair condition (desiccated). One specimen bears a tag that reads "Aphredoderus sternotremia isolepis, Union Co., 1877, type" and is herein designated the lectotype. The type locality is restricted thereby to small streams in Union County;

Callahan and Drury Creeks were listed as collecting localities in Union County at the beginning of Nelson's catalog (1876:33). The inexplicable discrepancy between the date of collection and presumed date of publication was noted by Smith and Bridges (1960).

Paralectotypes

[INHS $37830(2,32.9,49.1 \mathrm{~mm}$ SL); collection data same as lectotype; ISLNH acc. no. 26373].

TAXONOMIC Status

= Aphredoderus sayanus gibbosus

LeSueur 1833

According to Jordan (1877b:51), the conception of the name Sternotremia stemmed from Nelson's misunderstanding of the meaning of "sternon."

Sternotremia was criticized as "anatomically incorrect. . . the vent not being in the 'sternon', as in Aphododerus, but entirely behind it." Nelson in Jordan (1877b:51) responded with the more appropriate replacement name Asternotremia; however, this is an unjustified emendation of

Sternotremia. Jordan (1878a:48) verified S.A. Forbes' observations that the position of the vent was age dependent and thereby "not a character of generic importance." Jordan (1878a) subsequently synonymized Sternotremia with Aphododerus (= Aphredoderus LeSueur 1833) but retained $A$. isolepis as a valid species. 
Jordan and Gilbert (1883:461) and Jordan and Evermann (1896:787) later placed isolepis in the synonymy of $A$. sayanus (Gilliams 1824). In a study of geographic variation, Boltz and Stauffer (1993:81) recognized two valid subspecies, A. s. sayanus and A. $s$. gibbosus LeSueur 1833; isolepis is a junior synonym of $A$. s. gibbosus.

Donated Material

Paralectotypes

[MCZ 8576 (1)]; small, weedy tributary to the Calumet River near Chicago, [Cook County, Illinois; E.W. Nelson (EWN: Calumet)].

Remarks: Nelson's catalog (1876:33) specifies Cook County for his collections from the Calumet River and its tributaries. MCZ database (1994) indicates collecting locality as "Calumet River near Chicago" and collector as E.W. Nelson (field no. "EWN: Calumet") for specimen received 30 March 1877.

[USNM 17853 (1)]; small, weedy tributary to the Calumet River near Chicago, [Cook County, Illinois; D.S. Jordan; July 1876].

Remarks: Information on USNM type specimen is from the NMNH Fish Collection's online database (Williams 1996), which indicates collecting locality as "Calumet Riv. Ills.", collector as D.S. Jordan, and date as July 1876.

\section{AMBLYOPSIDAE}

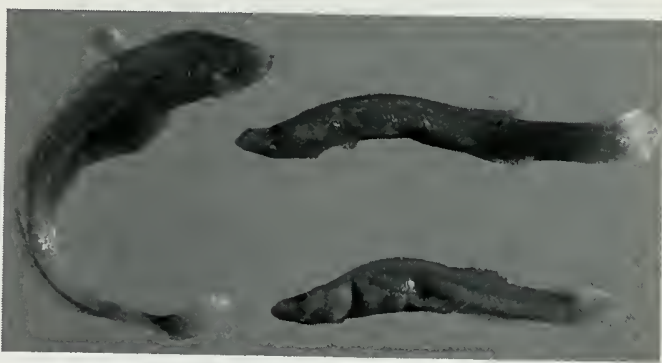

Chologaster papilliferus Forbes 1882.

Syntypes. INHS 26953, spring at the base of a limestone bluff [Pine Hills] in southern Illinois, Union County (=Forbesichthys agassizi).

Chologaster papilliferus Forbes 1882. Forbes 1882:2.

Syntypes

[INHS 26953 (3, 20.9-36.5 mm SL)]; spring at the base of a limestone bluff [Pine Hills] in southern Illinois, [western] Union County; F.S. Earle; [1881; ISLNH acc. no. 26374].

[INHS 86467 (1, $22.7 \mathrm{~mm} \mathrm{SL})$; locality and collector data same as INHS 26953; August 1878; ISLNH acc. no. 28305].

Remarks: Described from a syntypic series of eight specimens $(37 \mathrm{~mm}$ average TL) all collected from the same locality by F.S. Earle. Smith and Bridges (1960:253) recovered a collection of three specimens (INHS 26953) considered to be of the syntypic series. Another syntype (INHS 86467) was recently found and is apparently the original specimen presented to Forbes (see Forbes 1881). The largest individual (36.5 mm SL, INHS 26953) has a tag with the penciled notation "Types, S. A. F., Pine Hills, Union Co., Earle, 1881." The specimens are in fair to poor condition and were slightly distorted upon preservation.

TAXONOMIC STATUS

\section{= Forbesichthys agassizi $($ Putnam} 1872)

Jordan and Evermann (1927:503) proposed the generic name Forbesella for papilliferus on the basis of this species' tactile papillae, which they considered absent in Chologaster 
cornuta Agassiz 1853. Informed of

Forbesella's preoccupation (in the tunicates), Jordan (1929b:68) proposed Forbesichthys Jordan and Evermann as a replacement name. Woods and Inger (1957:235) verified the presence of tactile papillae in $C$. cornuta and synonymized Forbesichthys with Chologaster despite acknowledging the two as "quite distinct" morphologically. Woods and Inger (1957:238) also synonymized the species papilliferus with Chologaster agassizi Putnam 1872, considering differences between the two nominal forms to be subspecific at most. In a phylogenetic analysis of electrophoretic and morphological data, Swofford (1982) found no evidence to unequivocally support the congeneric relationship of $C$. agassizi and $C$. cornuta and recommended the resurrection of Forbesichthys. Although papilliferus remains in synonymy, Forbesichthys agassizi is currently recognized by Page and Burr (1991), Mayden et al. (1992), and Etnier and Starnes (1993). Robins et al. (1991) retained the genus Chologaster. DONATED MATERIAL

Syntype

[MCZ 25180 (1); collection data same as INHS 26953; ISLNH acc. no. 26374].

\section{OPHIDIIDAE}

Neobythites unicolor Nielsen and Retzer 1994. Nielsen and Retzer 1994:993, Fig. 2a. Holotype

FMNH 69349 (90 mm SL, female); E. Caribbean Sea $\left(17^{\circ} 38^{\prime} 30^{\prime \prime} \mathrm{N}, 63^{\circ}\right.$ $27^{\prime} \mathrm{W}$ ), bottom trawl, $348 \mathrm{~m}$ (Oregon station 2633); 30 September 1959.

Paratype

INHS $32130(1,33 \mathrm{~mm} \mathrm{SL}$, sex unknown); West Caribbean Sea [off Cozumel Island, Quintana Roo, Mexico] $\left(20^{\circ} 26.3^{\prime} \mathrm{N}, 87^{\circ} 14.7^{\prime} \mathrm{W}\right), 10^{\prime}$ otter trawl, 253-276 m (MBI station 167); [Marine Biomedical Institute (field no. 6207)]; 11 April 1976; [ex. TCWC 6207.02].

\section{FUNDULIDAE}

Fundulus euryzonus Suttkus and Cashner 1981.

Suttkus and Cashner 1981:2, Figs. 1a, 2a, 3a.

Holotype

TU 116631 (65.4 mm SL, adult male); East Fork Big Creek, trib Tangipahoa

River $11.2 \mathrm{~km}$ E of Arcola, Tangipahoa Parish, Louisiana; R.D. Suttkus, R. Reynolds and J. Reynolds (RDS 7283); 4 March 1980.

Paratypes

INHS 87086 (10, 25.9-59.6 mm SL); East Fork Big Creek [Lake Ponchartrain drainage] $7.5 \mathrm{~km}$ E of Arcola, Hwy 1054, Tangipahoa Parish, Louisiana; R.D. Suttkus, et al. (RDS 5180); 10 March 1972.

Fundulus julisia Williams and Etnier 1982. Williams and Etnier 1982:11, Figs. 2 (bottom), 3.

Holotype

USNM 225997 (53.8 mm SL, adult male); spring tributary to West Fork Hickory Creek, Caney Fork River system, Cumberland River drainage, at Tennessee Highway 55, 0.3 rd. mile northeast of junction with County Road 4292, Summitville, Coffee County, Tennessee (spring originates from cave on Joseph R. Banks property on north side of Tennessee Highway 55); D. Etnier, R. Bouchard, and F.V. Oakberg; 1 April 1973.

Paratopotypes

INHS 87282 (2); [W.M. Howell and S.K. Osborn]; 14 June 1979; originally property of Samford University, Birmingham, Alabama. 


\section{CENTRARCHIDAE}

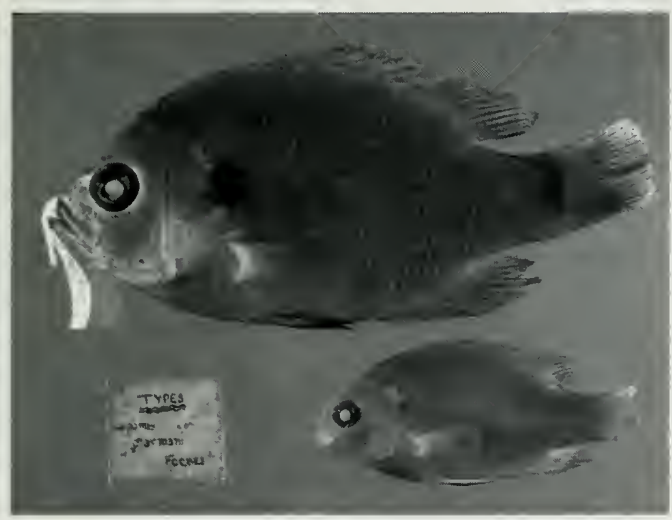

Lepomis garmani Forbes 1885 . Syntypes. INHS 26955, Little Fox River at Phillipstown and Wabash River and Drew Pond at Carmi, [White County], Illinois (= Lepomis miniatus).

\section{Lepomis garmani Forbes 1885.}

Forbes 1885:135.

Syntypes

[INHS 26955 (5, 58.1-104.1 mm SL)]; Little Fox River at Phillipstown and Wabash River and Drew Pond at Carmi, [Wabash River drainage, White County], Illinois; [H. Garman; 3 and 5 October 1882; ISLNH acc. nos. 2828 and 2836].

Remarks: Original description based on syntypic series of 15 specimens, 5 of which were found by Smith and Bridges (1960:254). Original label with lot specifies "types" from "Little Fox River and Drew Pond." Two specimens $(58.3,99.6 \mathrm{~mm} \mathrm{SL})$ bear tags indicating accession number 2828 , which corresponds to Wabash River and Drew Pond at Carmi, 3 October 1882. The three remaining syntypes (58.1-104.1 mm SL) are without accession tags attached but were presumably accessioned as ISLNH 2836, which specifies Little Fox River at Phillipstown, 5 October 1882.

\section{Taxonomic Status}

= Lepomis miniatus (Jordan 1877b)

Jordan and Evermann (1896:1002) questioned the distinctness of Lepomis garmani from L. miniatus (Jordan $1877 \mathrm{~b}$ ), the species with which it was eventually synonymized (Richardson
1904:33). In an unpublished revision of Centrarchidae, Bailey (1938) placed L. miniatus in L. punctatus (Valenciennes in Cuvier and Valenciennes 1831) recognizing Lepomis punctatus miniatus as a subspecies. This subspecies designation was commonly accepted until Warren (1992) demonstrated L. miniatus and $L$. punctatus to be distinct species, a distinction accepted by Mayden et al. (1992) and Etnier and Starnes (1993).

DONATEd Material

Syntype

[CAS-SU 2414 (1, $75.3 \mathrm{~mm} \mathrm{SL})]$; Little Fox River at Phillipstown [Wabash River Drainage, White County], Illinois; [H. Garman; 5 October 1882; ISLNH acc. no. 2836]. Remarks: Syntype reported by Böhlke (1953:71).

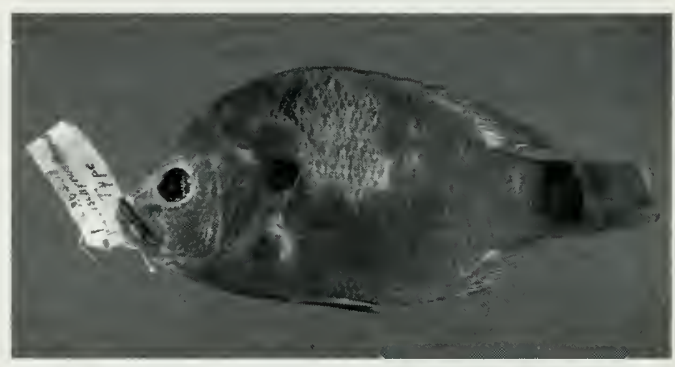

Lepiopomus ischyrus Jordan and Nelson 1877.

Lectotype. INHS 26954, Illinois River [between LaSalle and Pekin], Illinois (= Lepomis cyanellus $\mathrm{x}$ L. macrochirus).

Lepiopomus ischyrus Jordan and Nelson 1877. in Jordan 1877b:25.

Lectotype

[INHS 26954] (7 in. long, adult); Illinois River [between LaSalle and Pekin], Illinois; [ISLNH acc. no. 26408].

Remarks: Species based on two specimens, one of which was located by Smith and Bridges (1960:253) and is here designated the lectotype (see taxonomic status). The specimen (144.5 mm SL) is poorly preserved and bears a cloth tag with "type" printed in ink. A second handwritten tag placed with the specimen bears the informa- 
tion " $L$. ischyrus = hybrid Apomotis cyanellus x Helioperca macrochira, R. M. Bailey, 16 January 1938."

Paralectotype

Missing: The second specimen, collected from the Fox River at Geneva, [Kane County], Illinois, was retained in E.W. Nelson's collection (Nelson 1876:37) and is presumed lost.

\section{TAXonomic Status}

= Lepomis cyanellus Rafinesque 1819

x L. macrochirus Rafinesque 1819

The taxonomic history of this name is convoluted. In a partial catalog of Illinois fishes, Nelson (1876:37) referred Pomotis aquilensis Baird and Girard 1853 to the genus Ichthelis Rafinesque 1820 as "I. aquiliensis [sic], (Grd.) Nelson" based on two specimens collected from the Illinois and Fox rivers. Nelson's (1876:38) account included a detailed description of the larger specimen (Illinois River), which is herein designated the lectotype (INHS 26954). Jordan and Nelson in Jordan (1877b:25) concluded that the species identified by Nelson (1876) was not Pomotis aquilensis, but, in fact, a new species that they named

Lepioponuls ischyrus and described by bibliographic reference. Often considered rare, this species was subsequently recognized in numerous manuals and checklists (see Bailey 1938) including The Fishes of Illinois (Forbes and Richardson 1909, 1920 [2nd ed.]:250). The validity of ischyrus was questioned by Jordan (1929a: 146) and Hubbs (in Jordan et al. 1930:299), both of whom thought it to be a hybrid. Based on specimens produced from experimental crosses, Hubbs and Hubbs (1932:436) considered the name Lepioponus ischyrus to be based on the hybrid Apomotis cyanellus (Rafinesque 1819) $\mathrm{x}$ Helioperca incisor (Valenciennes 1831). Bailey (1938) examined the type specimen and effectively synonymized Lepiopomus ischyrus with the hybrid cross Lepomis cyanellus $\mathrm{x} L$. macrochirus $(=A$. cyanellus $\times H$. incisor of Hubbs and Hubbs 1932).

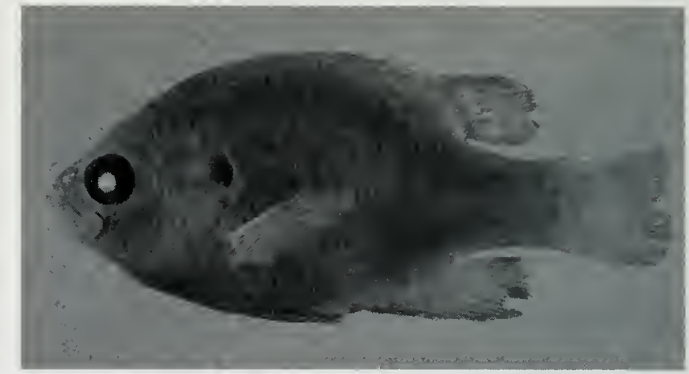

Lepomis symmetricus Forbes 1883 . Lectotype. INHS 75004, Illinois River [at Pekin, Tazewell County, Illinois].

Lepomis symmetricus Forbes 1883. in Jordan and Gilbert 1883:473.

Lectotype

[INHS 75004 (39.5 mm SL, juvenile)]; Illinois River [(Mississippi River drainage) at Pekin, Tazewell County, Illinois; 16 April 1880; ISLNH acc. no. 220].

Remarks: Original description based on syntypic series of 15 specimens, all of which are extant and in a good state of preservation. Burr (1977:442) designated the lectotype from a lot of eight specimens (ISLNH acc. no. 220) recovered by Smith and Bridges (1960:254). This lot is accompanied by a handwritten label bearing the information "Types Lepomis symmetricus Forbes." Measurements of type material determined by Burr (1977).

Paralectotypes

[INHS 75005 (7, 32.7-36.2 mm SL); collection data same as lectotype; ISLNH acc. no. 220].

[INHS 75006 (2, 50.1-51.2 mm SL); locality data same as lectotype; 2 June 1880; ISLNH acc. no. 226].

DONATEd MATERIAL

Paralectotypes

[MCZ 25014 (1, $49.5 \mathrm{~mm}$ SL), CASSU 1276 (3, 49.8-56.9 mm SL), USNM 29864 (1, $51.0 \mathrm{~mm}$ SL); locality data same as lectotype; 16 April and 2 June 1880; 1SLNH acc. nos. 220 and 226]. 


\section{PERCIDAE}

Etheostoma aquali Williams and Etnier 1978. Williams and Etnier 1978:464, Fig. 1.

Holotype

TU 105479 (55 mm SL, adult male);

Flat Creek, tributary to Duck River at

Tennessee Highway 64, Bedford

County, Tennessee; 13 April 1967.

Allotype

TU 105480 (43 mm SL, adult female).

\section{Paratypes}

INHS 77826 (3); Duck River at mouth of Hurricane Creek, Humphreys

County, Tennessee; [D.A. Etnier, G.F.

Boronow, F.V. Oakberg, W.C.

Dickinson, Clark and Henson]; 29

August 1973; [ex. UT 91.829].

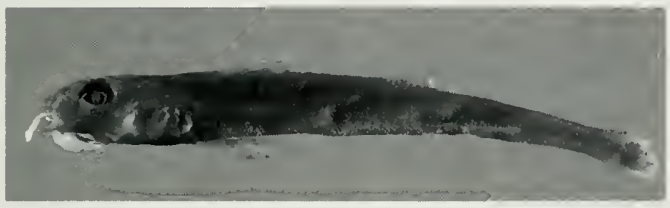

Pleurolepis asprellus Jordan 1878. Holotype.

INHS 26971, small rocky tributary of the Mississippi River [at Warsaw], Hancock County, Illinois (= Crystallaria asprella).

Pleurolepis asprellus Jordan 1878.

Jordan 1878a:38.

Holotype

[INHS 26971] (4 1/3 in. long); small rocky tributary of the Mississippi River [at Warsaw], Hancock County, Illinois; C.K. Worthen; [1877].

Remarks: Original description designated one of two specimens collected from the locality above as the "type." A specimen recovered from ISLNH measured $97.5 \mathrm{~mm}$ (3.80 in.) TL, $90 \mathrm{~mm}$ (3.51 in.) SL compared to $41 / 3$ in. (111.1 mm) "length" (=TL?) given in the original description. The specimen is presumed to be the "type" (= holotype in Collette and Knapp 1967), the discrepancy in length attributed to its severe desiccation. The specimen bears a tag with the information "Warsaw, $1877 \mathrm{Cl}$."
Paratypes

Missing: The second of the two specimens indicated above (= paratopotype) is missing. In addition, the original description mentions "numerous specimens in the State collection [ISLNH], some about 2 1/3 inches long, taken by Prof. Forbes in the Little Wabash River. . . in Effingham Co. [1llinois], in July [1877]." None of these specimens were found at INHS.

TAXONOMIC STATUS

= Crystallaria asprella (Jordan 1878a) Jordan and Gilbert (1883:488) placed Pleurolepis Agassiz in Putnam 1863 in synonymy with Ammocrypta Jordan 1877b. The species asprella was later assigned to a new monotypic genus Crystallaria proposed by Jordan and Gilbert in Jordan (1885:78). Bailey and Gosline (1955:10) treated Crystallaria as a subgenus of Ammocrypta. The subgenus Crystallaria was later diagnosed by Page (1981:28). Based on a phylogenetic analysis of osteology and external morphology, Simons (1992:288) recommended the resurrection of Crystallaria as a monotypic genus. Page and Burr (1991) and Mayden et al. (1992) accepted the generic rank of Crystallaria, but Robins et al. (1991) retained the use of Anmocrypta. Collete and Knapp (1967:9) noted that Pleurolepis Agassiz in Putnam 1863 is preoccupied in Semionotidae (gars) by Pleurolepis Quenstedt 1852 and thereby unavailable as a generic name for asprella.

Percina aurora Suttkus and Thompson 1994. in Suttkus, Thompson, and Bart 1994:15, Fig. 2.

Holotype

TU 101392 (59.7 mm SL, adult male); Strong River, tributary to Pearl River at rapids, 0.2 mi upstream from Miss. Hwy 28 bridge, 2 miles W Pinola (T1N, R3E, Sec. 28), Simpson County, Mississippi; R.D. Suttkus and D.

O'Donnell Remington; 12 March 1969. Paratopotype

INHS 32133 (1); [R.D. Suttkus, J.S. 
Suttkus, and M. Andersson (RDS

2697)]; 3 April 1958; ex. TU 17732.

Percina austroperca Thompson 1995.

Thompson 1995:3, Fig. 1a.

Holotype

UF 47334 (128.3 mm SL, adult male); Holmes Creek, tributary to

Choctawhatchee River, near New Hope (T2N, R16W, Sec. 16-22), Washington County, Florida; G. Bass et al.; 16 January 1980.

Paratype

INHS 86973 (1, $101.4 \mathrm{~mm} \mathrm{SL)}$;

Escambia Creek (Escambia River drainage), 6.4 km E Flomaton, Hwy. 29

(T1N, R9E, Sec. 30), Escambia County, Alabama; [D.L. Swofford, L.M. Page, and E.A. Lisowski]; 24 June 1980.

Etheostoma baileyi Page and Burr 1982.

Page and Burr 1982:2, Fig. 1a.

Holotype

INHS $87484(43.0 \mathrm{~mm} \mathrm{SL}$, adult male); Little Sexton Creek, tributary of South Fork Kentucky River, $2 \mathrm{~km}$ E (town of) Sextons Creek (37 $19^{\prime} \mathrm{N}, 83^{\circ}$ $45^{\prime}$ W), Clay County, Kentucky; W.L.

Keller, L.E. Cordes, and L.M. Page; 20 May 1980.

Paratopotypes

INHS 86871 (12, 30-42 mm SL).

Donated Material

Paratopotypes

KU 19109 (9, 29-41 mm SL), and UT

$91.2360(9,28-42 \mathrm{~mm}$ SL); [R.L.

Mayden and L.M. Page]; 22 March

1978; [ex. INHS 79197].

Etheostoma barrenense Burr and Page 1982.

in Page and Burr 1982:15, Fig. 1c.

Holotype

INHS 87491 (48.8 mm SL, adult male); Trammel Creek, tributary of Drakes Creek, $3 \mathrm{~km} \mathrm{SW}$ Halfway $\left(36^{\circ}\right.$ $48^{\prime} \mathrm{N}, 86^{\circ} 18^{\prime} \mathrm{W}$ ), Allen County, Kentucky; L.M. Page and B.M. Burr; 25 May 1981.

Paratopotypes

INHS 87492 (12, 32-47 mm SL).

Donated Material

Paratypes

KU $19110(7,33-43 \mathrm{~mm} \mathrm{SL})$, and UT
91.2358 (6, 37-42 mm SL); Trammel Creek, 6 km SSW Scottsville, Allen County, Kentucky; [R.L. Mayden and L.M. Page]; 13 April 1978; [both ex. INHS 79290].

Etheostoma bison Ceas and Page 1997.

Ceas and Page 1997:518, Fig. 1H.

Holotype

INHS 37506 (53.5 mm SL, breeding male); North Fork Buffalo River, 5.6 $\mathrm{km}$ N Three Oaks at US 43, Lawrence County, Tennessee; L.M. Page and R.L. Mayden; 14 April 1978.

Remarks: Holotype was figured (Plate 30G) in Page (1983), where it is listed as $56 \mathrm{~mm}$ SL.

Paratopotype

INHS 79311 (1, 56.0 mm SL).

Paratypes

INHS 27851 (8, 32.8-46.5 mm SL);

Brewer Branch (Buffalo River system), $1.6 \mathrm{~km}$ E Brace at Three Oaks Rd., Lawrence County, Tennessee; L.M. Page, [P.A. Ceas, J.W. Armbruster, C.E. Johnston, C.A. Laird, and J.E. Janovetz]; 4 April 1992.

INHS $32416(20,31.8-45.3 \mathrm{~mm}$ SL); Stewarts Branch, Hurricane Creek (Duck River system), $3.2 \mathrm{~km} \mathrm{NE}$ Hurricane Mills at Hwy 13, Humphreys County, Tennessee; P.A. Ceas; 29 March 1994.

INHS 58182 (4, 37.2-46.8 mm SL); Pinhook Branch, White Oak Creek (Tennessee River system), 1.6 km NE Woolworth at Hwy 13, Humphreys County, Tennessee; L.M. Page and P.A. Ceas; 19 March 1990.

\section{DONATED MATERIAL}

Paratypes

SIUC 25128 (5, 38.3-48.7 mm SL); ex. INHS 32416.

TU 177765 (5, 32.0-46.8 mm SL); locality data same as INHS 32416; P.A. Ceas, H.L. Bart, and L.M. Page; 8 April 1988; ex. INHS 63898.

UMMZ 231178 (3, 41.0-45.6 mm SL); ex. INHS 58182.

USNM 3309905 (3, 44.5-48.9 mm SL); South Fork Buffalo River, $2.4 \mathrm{~km} \mathrm{~N}$ Webber City at US 43, Lawrence County, Tennessee; P.A. Ceas; 19 April 1990; ex. INHS 58418. 
UT 91.4754 (5, 30.0-54.6 mm SL); ex. INHS 27851.

Percina brevicauda Suttkus and Bart 1994. in Suttkus, Thompson, and Bart 1994:20, Fig. 3.

Holotype

TU 101393 (45.8 mm SL, adult male); Cahaba River, tributary to Alabama River at Alabama Hwy 52, $3.2 \mathrm{mi}$ W of Helena (T20S, R3W, Sec. 20), Shelby County, Alabama; R.D. Suttkus and G.H. Clemmer; 10 May 1965.

Paratopotypes

INHS 32132 (4); [R.D. Suttkus and D. Nieland (RDS 7555)]; 16 May 1981; [ex. TU 121415].

Etheostoma brevirostrum Suttkus and Etnier 1991.

Suttkus and Etnier 1991:15, Fig. 2.

Holotype

TU 158216 (40.7 mm SL, adult male); Shoal Creek, tributary to Choccolocco Creek at Pine Glen Recreation Area, 8.I mi N of US Hwy 78, (T15S, R10E, Sec. 16), Cleburne County, Alabama; R.D. Suttkus and J.M. Pierson; 10 May 1989.

\section{Paratypes}

INHS 59306 (2); Shoal Creek (Coosa

River system), $2.3 \mathrm{mi}$ E White Plains at Whitesides Mill, TI5S, R9E, Sec. 12, Calhoun County, Alabama; [R.D. Suttkus, G.E. Gunning, R.C. Cashner, and B.A. Thompson]; 14 October 1969; ex. TU 59644.

\section{Etheostoma burri Ceas and Page 1997}

Ceas and Page 1997:514, Fig. 1E.

Holotype

INHS 37503 (50.1 mm SL, breeding male); Mill Spring (Black River), NE edge of town of Mill Spring, Wayne County, Missouri, T28N, R3E, Sec. 25, SE/4; P.A. Ceas; 25 April 1992.

Paratopotypes

INHS 27904 (26, 29.5-51.2 mm SL).

DONATED MATERIAL

Paratopotypes

USNM 339902 (5, 30.5-49.5); P.A.

Ceas; 11 April 1994; ex. INHS 32586.

Paratypes

UT 91.4751 (5, 36.1-46.1 mm SL);
Swift Creek (Black River), $4.0 \mathrm{~km} \mathrm{NW}$ Hendrickson at Hwy JJ, Butler County, Missouri, T26N, R5E, Sec. 9, SE/4; P.A. Ceas, [L.M. Page, G.B. Mottesi, L.L. Foersom, and M. Molis]; [20] March 1992; ex. INHS 27812.

Remarks: Date incorrectly listed as "29" March 1992 in Ceas and Page (1997:515).

UAIC $11345.01(5,33.7-45.4 \mathrm{~mm} \mathrm{SL})$, UMMZ 231175 (5, 37.2-43.4 mm SL),

TU 177762 (5, 37.0-43.4 mm SL); unnamed tributary, Black River, 1.6 km SE Hendrickson at Hwy O, Butler County, Missouri, T26N, R6E, Sec. 19, NW/4; P.A. Ceas; 24 April 1994; all ex. INHS 32671.

Etheostoma chienense Page and Ceas 1992. in Page, Ceas, Swofford, and Buth 1992:627, Figs. 1g, 2g.

Holotype

INHS 58454 (57.8 mm SL, breeding male); Jackson Creek, 2.6 km NE Water Valley on Roy Lawrence Drive, Graves County, Kentucky; L.M. Page and P.A. Ceas; 18 March 1990.

Paratopotypes

INHS 58221 (33, 34.5-71.4 mm SL).

Donated MATERIAL

Paratopotypes

UAIC 9998.01 (5, 47.0-65.3 mm SL),

SIUC 18067 (5, 46.7-63.9 mm SL), UMMZ 217893 (5, 47.5-64.8 mm SL), USNM $313758(5,41.2-68.3 \mathrm{~mm} \mathrm{SL})$ and UT 91.3849 (5, 47.1-67.9 mm SL); P.A. Ceas, H.L. Bart, Jr., and L.M. Page; 7 April 1988; all ex. INHS 63920 .

Etheostoma chuckwachatte Mayden and Wood 1993.

in Wood and Mayden 1993:39, Fig. 3d, e. Holotype

UAIC 9815.07 (45.5 mm SL, adult male); Hillabee Creek at Alabama Hwy 22, $11.7 \mathrm{~km}$ NE of Alexander City, T23N, R22E, Sec. 16, Tallapoosa County, Alabama; R.M. Wood, R.L. Mayden, B.R. Kuhajda, and S.R. Layman; 3 February 1990.

Paratopotypes

INHS 28459 (2, 37.5-39.7 mm SL); [ex. UAIC 9815.02]. 
Etheostoma corona Page and Ceas 1992. in Page, Ceas, Swofford, and Buth 1992:631, Figs. 1d, 2c.

Holotype

INHS 64073 (59.5 mm SL, breeding male); Little Cypress Creek (Tennessee River Drainage), 2.4 km NW Cross roads, Wayne County, Tennessee; P.A. Ceas, H.L. Bart, Jr., and L.M. Page; 8 April 1988.

Paratopotypes

INHS $62819(24,23.5-64.4 \mathrm{~mm} \mathrm{SL})$;

L.M. Page, C.E. Johnston, and P.A. Ceas; 13 April 1987.

Donated Material

Paratypes

SIUC 18066 (3, 31.6-55.3 mm SL), UMMZ 217889 (3, 32.7-55.0), USNM 313754 (3, 36.1-49.5 mm SL), and UT 91.3848 (3, 33.2-67.1); Cypress Creek, 9.7 km S Collinwood, Wayne County, Tennessee; M.E. Braasch; 15 April 1978; all ex. INHS 84171.

Etheostoma crossopterum Braasch and Mayden 1985.

Braasch and Mayden 1985:15, Figs. 2d, 3d, 8, 10 (upper).

Holotype

KU 20896 (69.8 mm SL, breeding male); McKnight Branch, 8 km N Readyville, Rutherford County,

Tennessee; M.E. Braasch; 2 April 1980. Paratypes

INHS 74918 (26, 29.0-57.0 mm SL); East Fork Stones River [Cumberland River Drainage] at Lofton, Rutherford County, Tennessee; [M.A. Morris, B.M. Burr, and L.M. Page]; 14 March 1976.

Etheostoma douglasi Wood and Mayden 1993. Wood and Mayden 1993:37, Fig. 3 b.

Holotype

UAIC $10345.02(51.2 \mathrm{~mm}$ SL, adult male); West Fork Sipsey River at Lawrence Co. Rd. 6, Sipsey River Recreational Site, T9S, R8W, Sec. 8, Winston County, Alabama; R.M.

Wood, S.R. Layman, and A.M. Simons; 14 March 1991.

Paratopotypes

INHS 28458 (3, 33.4-45.3 mm SL);
R.L. Mayden and B.R. Kuhajda; 2

March 1992; [ex. UAIC 10273.01].

Etheostoma etowahae Wood and Mayden 1993.

Wood and Mayden 1993:38, Fig. 3c.

Holotype

UAIC 9169.14 (54.7 mm SL, adult male); Etowah River at Georgia Hwy $52,13.7 \mathrm{~km}$ NNE of Dawsonville, Lumpkin County, Georgia; R.M. Wood, R.L. Mayden, B.R. Kuhajda, R.H. Matson, and M.T. Ferguson; 5 April 1989.

Paratopotypes

INHS $28460(2,45.6-46.6 \mathrm{~mm}$ SL); [ex. UAIC 9169.11].

Etheostoma flavum Etnier and Bailey 1989.

Etnier and Bailey 1989:3, Pl. 1.

Holotype

UMMZ 213929 (49.0 mm SL, adult male); Elk Fork Creek at U.S. Hwy. 79, 9.5 air km NE of Guthrie, Todd County, Kentucky; C.R. Gilbert and F.A. Gilbert; 21 June 1957.

Paratypes

INHS 68219 (23, [35-52 mm SL]); Whiteoak Creek (small eastern tributary to lower Tennessee River) at co. rd. 6261, 19.6 km NNW Waverly, Houston County, Tennessee; [W.C. Starnes, W.C. Dickinson, A.E. Bogan, M.H. Hughes, D.A. Etnier, G.A. Schuster, G.F. Boronow, T.J. Timmons, E.M. Scott, B. Bauer, and B. Martin; 26 October 1974].

Etheostoma forbesi Page and Ceas 1992. in Page, Ceas, Swofford, and Buth:633, Figs. 1c, 2d.

Holotype

INHS 58632 (73.9 mm SL, breeding male); Duke Creek, 3.2 km SE Hollow Springs, Cannon County, Tennessee; P.A. Ceas; 19 April 1990.

Paratopotype

INHS $58359(1,74.4 \mathrm{~mm} \mathrm{SL})$.

DONATED MATERIAL

Paratopotypes

UMMZ 217892 (3, 46.8-58.3 mm SL) and USNM $313756(3,42.7-54.5 \mathrm{~mm}$ SL); L.M. Page and P.A. Ceas; 19 March 1989; both ex. INHS 64680. 


\section{Percina caprodes fulvitaenia Morris and Page} 1981.

Morris and Page 1981:96, Figs. 1, 2 b.

Holotype

INHS 75633 (127 mm SL, adult male); Big Piney River (Gasconade River Drainage), $5 \mathrm{~km}$ W Houston, Texas County, Missouri; B.M. Burr and P.A. Grubb; 7 May 1976.

Paratypes

INHS 75631 (2, 56-99 mm SL);

Gasconade River, 6 km S Jerome, Phelps County, Missouri; [E. M. Lowry; 11-14 September 1948].

INHS 79415 (2, 127-131 mm SL); Big Piney River [Gasconade River Drainage], 1 km E Simmons, Texas County, Missouri; [L.M. Page, P.W. Smith, and D.M. Smith; 25 April 1978].

Donated Material

Paratypes

TU 110587 (2, 86-98 mm SL); Maries River [Missouri River Drainage], 2 km S Westphalia, Osage County, Missouri; [P.W. Smith and L.M. Page; 11 October 1969; ex. INHS 75634].

USNM 219366 (3, 86-95 $\mathrm{mm} \mathrm{SL})$, and UT 91.1716 (3, 70-85 mm SL); Pomme de Terre River [Osage River Drainage], $3 \mathrm{~km}$ SW Hermitage [T37N, R22W, Sec. 34], Hickory County, Missouri; [E.M. Lowry; 11-19 May 1948; both ex. INHS 75628].

\section{Percina gymnocephala Beckham 1980.}

Beckham 1980:1, Fig. 1.

Holotype

TU 106911 (63.8 mm SL, adult female); South Fork of New River at eastern crossing of co. rd. 1181, 7.0 airmi. SE of West Jefferson, Ashe County, North Carolina; E.C. Beckham and E.B. Beckham; 22 September 1977. Paratypes

INHS 27291 (2, [60.5-65.1 mm SL]); South Fork of New River at Co. Rd. 1105, Ashe County, North Carolina; [H. Bart, R. Hozenthal, J. Grady, and G. Laiche]; 24 March 1978; [ex. TU 106912].
Percina jenkinsi Thompson 1985.

Thompson 1985:4, Fig. 1 a.

Holotype

TU 106075 (113.3 mm SL, adult male); Conasauga River (Mobile Bay Drainage), Tennessee Hwy 74, $20 \mathrm{~km} \mathrm{SE}$ Cleveland, Bradley County, Tennessee; B.A. Thompson, D.A. Etnier, and University of Tennessee students (BAT-72-451); 1 July 1972.

Paratopotype

INHS 74582 (1, $93.3 \mathrm{~mm}$ SL); [L.M. Page and D.W. Webb]; 13 October 1971.

Etheostoma kantuckeense Ceas and Page 1997 Ceas and Page 1997:517, Fig. 1G.

Holotype

INHS 37505 (46.2 mm SL, breeding male); Sharps Branch, West Fork Drakes Creek, $4.0 \mathrm{~km} \mathrm{~S}$ Franklin at County Road 1522 (Lake Spring Road), $0.6 \mathrm{~km} \mathrm{~W}$ of US $31 \mathrm{~W}$, Simpson County, Kentucky; P.A. Ceas; 26 March 1994.

Paratopotypes

INHS 32395 (15, 37.0-51.8 mm SL).

DONATED MATERIAL

Paratopotypes

SIUC 25127 (5, 37.6-48.1 mm SL), TU 177764 (5, 38.8-46.8 mm SL), UAIC 11347.01 (5, 38.7-47.0 mm SL), UMMZ 231177 (5, 38.7-47.0 mm SL), USNM 339904 (5, 37.0-50.1 mm SL), and UT 91.4753 (5, 39.3-50.2 $\mathrm{mm} \mathrm{SL})$; L.M. Page and P.A. Ceas; 21 March 1989; all ex. INHS 64553.

Etheostoma nigripinne Braasch and Mayden 1985.

Braasch and Mayden 1985:28, Figs. 2e, 3e, 10 (bottom), 11.

Holotype

KU 20000 (56.5 mm SL, breeding male); Pikes Peak Branch, tributary to the Tennessee River $1.6 \mathrm{~km}$ W of TN Rt. 20 bridge, Decatur County, Tennessee; M.E. Braasch; 5 April 1981.

\section{Paratypes}

INHS 68092 (7, 33.8-62 mm SL); small tributary to Tennessee River, 0.5 km W Tennessee River on TN Rt. 20, 
Decatur County, Tennessee; [M.E. Braasch]; 14 May 1978; [ex. KU 20893].

Etheostoma olivaceum Braasch and Page 1979.

Braasch and Page 1979:2, Figs. 1, 2a, b.

\section{Holotype}

INHS 75734 (50.5 mm SL, adult male); Rock Springs Branch at Rock Springs Church, $2 \mathrm{~km} N$ Buffalo Valley $\left(36^{\circ} 10^{\prime} \mathrm{N}, 85^{\circ} 47^{\prime} \mathrm{W}\right)$, Putnam County, Tennessee; B.M. Burr and L.M. Page; 14 June 1975.

Paratopotypes

INHS 75735 (10, 36-58 mm SL), INHS $75576(8,35-64$ mm SL); 11 December 1976.

DONATED MATERIAL

Paratopotypes

USNM 216895 (6, 34-46 mm SL), UMMZ 200208 (6, 35-48 $\mathrm{mm} \mathrm{SL})$, and UT 91.1332 $(6,37-45 \mathrm{~mm} \mathrm{SL})$; all ex. INHS 75735.

TU 101391 (6, 37-50 mm SL), UAIC 5341.01 (6, 39-48 mm SL), NLU 35160 (6, 41-51 mm SL); 11 December 1976; all ex. INHS 75576.

Etheostoma oophylax Ceas and Page 1992. in Page, Ceas, Swofford, and Buth 1992:629, Figs. 1h, 2j.

Holotype

INHS 59110 (49.5 mm SL, breeding male); Little Bacon Creek (tributary of Big Sandy River), $3.2 \mathrm{~km} \mathrm{NE}$ Clarksburg, Carroll County, Tennessee; P.A. Ceas and L.M. Page; 24 April 1986.

Paratopotypes

INHS $61820(6,39.0-73.8 \mathrm{~mm} \mathrm{SL})$.

Donated Material

Paratopotypes

UAIC 9999.01 (3, 44.7-54.7 mm SL), SIUC 18065 (3, 37.4-59.7 mm SL), UMMZ 217891 (3, 38.6-66.7 mm SL), USNM 313755 (3, 39.5-52.0 mm SL), and UT 91.3847 (3, 41.2-56.2 $\mathrm{mm} \mathrm{SL)}$; all ex. INHS 61820.

Etheostoma pseudovulatum Page and Ceas 1992.

in Page, Ceas, Swofford, and Buth 1992:628, Figs. lj, k, 2 h.
Holotype

INHS 58630 (56.0 $\mathrm{mm}$ SL, breeding male); Mill Creek, $1.6 \mathrm{~km} \mathrm{~S}$ Wrigley at Hwy 100 bridge, Hickman County, Tennessee; L.M. Page, P.A. Ceas, and

C.E. Johnston; 11 April 1987.

Paratopotypes

INHS 62825 (35, 25.9-60.0 mm SL).

DonAted Material

Paratopotypes

SIUC 18064 (3, 39.2-57.4 mm SL), UAIC 9997.01 (3, 43.1-54.3 mm SL), UMMZ 217890 (3, 51.0-53.4 mm SL), and USNM 313757 (3, 36.0-61.2 mm SL); P.A. Ceas; 16 April 1990; all ex. INHS 58452.

Etheostoma pyrrhogaster Bailey and Etnier 1988.

Bailey and Etnier 1988:31, PI. 1 (upper). Holotype

UMMZ 213924 (56.6 mm SL, adult male); Clear Creek, tributary to North Fork Obion River, at unnumbered county road crossing 2.7 air $\mathrm{km} \mathrm{S} \mathrm{Co.}$ Rd. 8172, 5.1 air km SW Puryear, Henry County, Tennessee; J.E. Deck, W.C. Dickinson, and J. Vaughn; 30 October 1971.

Paratopotypes

INHS 68217 (3); [W.C. Dickinson]; 13 March 1972.

Remarks: Collection date indicated as 31 March 1972 on handwritten tag with specimens.

Etheostoma rafinesquei Burr and Page 1982. in Page and Burr 1982:9, Fig. $1 b$. Holotype

INHS 87488 (47.5 mm SL, adult male); Barren Run, tributary of North Fork Nolin River, $2 \mathrm{~km}$ NW (town of) Barren Run ( $37^{\circ} 30^{\prime} \mathrm{N}, 85^{\circ} 48^{\prime} \mathrm{W}$ ), LaRue County, Kentucky; B.M. Burr and L.M. Page; 29 May 1981.

Paratopotypes

INHS 87482 (11, 31-48 mm SL).

DONATEd Material

Paratopotypes

KU 19111 (11, 31-48 mm SL), UT 91.2359 (11, 31-46 mm SL), SIUC 1025 (11, 32-44 mm SL); [all ex. INHS 87482].

Remarks: Published account of 
paratype material incorrectly stated that 54 specimens were collected "with" the holotype. Forty-four specimens (originally cataloged as INHS 87482) were collected with the holotype, designated as paratypes and deposited at the museums listed above. The 10 additional specimens designated as paratypes were collected at the type locality on 27 September 1980 and are vouchered at the University of Florida, Florida State Museum (UF 32482) as indicated in the description.

Etheostoma scotti Bauer, Etnier and Burkhead 1995.

Bauer, Etnier, and Burkhead 1995:2, Fig. lb, c.

Holotype

UMMZ 223256 (47.2 mm SL, adult male); McCannless Creek, trib. to Shoal Creek, above GA Hwy. 108, at jct. GA 108 and Darby Rd., 1.75 airmi. S of center of Waleska, Cherokee County, Georgia: N.M. Burkhead, B.J. Freeman, C.R. Gilbert, S.J. Walsh, and J.D. Williams; 3 May 1990.

Paratypes

INHS 29400 ( $7,30-55$ mm SL); Four Mile Creek (Long Swamp Creek system) at Co. Rd. 52, 3.9 airmi. SE of Tate, Pickens County, Georgia; [N.M. Burkhead, B.J. Freeman, C.R. Gilbert, L.A. Somma, and S.J. Walsh (NMB 1292)]; 21 November 1991.

INHS 29644 (13, 35-54 mm SL); Sharp Mountain Creek (Sharp Mountain Creek system) at Co. Rd. 307, 3.7 airmi. SSW of Jasper, Pickens County, Georgia; [S.J. Walsh et al. (SJW 9223)]; 21 January 1992.

\section{Etheostoma blennius sequatchiense Burr} 1979.

Burr 1979:198, Fig. 1c, d.

\section{Holotype}

INHS $77589(61.7 \mathrm{~mm}$ SL, adult male); Sequatchie River, $1.6 \mathrm{~km} \mathrm{SE}$ Ninemile ( $\left.35^{\circ} 39^{\prime} \mathrm{N}, 85^{\circ} 7^{\prime} \mathrm{W}\right)$, Bledsoe County, Tennessee; B.M. Burr and L.M. Page; 10 August 1977.

Paratopotypes

INHS 77007 (10, 27-55 mm SL).
Etheostoma smithi Page and Braasch 1976.

Page and Braasch 1976:2, Figs. 1, 2 (left),

$3 \mathrm{a}, \mathrm{c}$

Holotype

INHS 75013 (51.7 mm SL, adult male); Ferguson Creek at the Rt. 70 bridge $\left(37^{\circ} 6^{\circ} \mathrm{N}, 87^{\circ} 24^{\prime} \mathrm{W}\right) 3 \mathrm{~km} \mathrm{E}$ Smithland, Livingston County, Kentucky; L.M. Page, B.M. Burr, and J.A. Boyd; 26 April 1975.

Paratopotypes

INHS 75014 (13, 25-51 mm SL).

Remarks: Date incorrectly indicated as 26 April 1971 in published account of paratopotype material.

DONATED MATERIAL

Paratopotypes

KU 16227 (14, 15-41 mm SL); [L.M. Page]; 29 May 1972; [collected with INHS 61186 (3 specimens)].

NLU 32515 (13, 23-50 mm SL); [L.J. Stannard and L.M. Page]; 20 February 1973; [collected with INHS 61180 (22 specimens)].

TU 95964 (13, 30-43 mm SL); [L.J. Stannard and L.M. Page]; 27 May 1971; [collected with INHS 61177 (2 specimens)].

UAIC 5021.01 (12, 23-47 mm SL); [L.M. Page]; 18 January 1972; [collected with INHS 68354 (73 specimens)].

UMMZ 197498 (24, 22-51 mm SL); [L.M. Page]; 22 April 1971.

USNM 214525 (24, 26-49 mm SL);

[L.M. Page]; 20 May 1973.

UT 91.1099 (8, 30-50 mm SL); [L.M. Page]; 3 May 1971.

Remarks: Paratopotype material listed above was not cataloged in the INHS collection prior to donation; INHS specimens collected with paratopotypes not included in published account of type material.

Percina stictogaster Burr and Page 1993.

Burr and Page 1993:19, Figs. 1 (middle and bottom), 3 .

Holotype

INHS 28535 (61.1 mm SL, adult male); Red Bird River, tributary of South Fork Kentucky River, at mouth of Jack's Creek, along Hwy. 66, at 
Eriline (Lat: $37^{\circ} 11^{\prime} 28^{\prime \prime}$; Long: $83^{\circ} 35^{\prime}$ 31"), Clay County, Kentucky; B.M.

Burr and R.R. Cicerello; 13 November 1992.

Paratopotypes

INHS 64304 (16, 33.6-57.3 mm SL);

[L.M. Page and K.S. Cummings]; 23

August 1988.

Donated Material

Paratopotypes

KU 23130 (2, 51.8-54.7); ex. INHS

64304

\section{Etheostoma striatulum Page and Braasch}

1977.

Page and Braasch 1977:1, Figs. 1, 2a, 3a, b.

Holotype

INHS 75035 (44.2 mm SL, adult male); Wartrace Creek [Duck River drainage] at the Tennessee Route 82 bridge, $2 \mathrm{~km}$ E Bell Buckle (35 $35^{\circ} \mathrm{N}$, $86^{\circ} 22^{\prime} \mathrm{W}$ ), Bedford County, Tennessee; L.M. Page, B.M. Burr, and M.A. Morris; 14 March 1976.

Paratopotypes

INHS $75036(16,25-47 \mathrm{~mm} \mathrm{SL})$.

INHS 75037 (9, 26-37 mm SL); [L.M.

Page and M.E. Braasch]; 7 November 1975.

DONATEd Material

Paratopotypes

UT 91.1174 (10, 22-37 mm SL), TU

97493 (10, 27-37 mm SL), NLU 33947

(10, 26-38 mm SL), USNM 213789

(10, 23-36 mm SL); all ex. INHS

75037.

Etheostoma tallapoosae Suttkus and Etnier 1991.

Suttkus and Etnier 1991:3, Fig. 1.

Holotype

TU 158215 (55.0 mm SL, adult male);

Gold Branch, tributary to

Channahatchee Creek at Alabama Hwy

63, $6 \mathrm{mi} \mathrm{N}$ of Eclectic (T20N, R21E,

Sec. 29), Elmore County, Alabama;

R.D. Suttkus, R.J. Miller, H.V. Miller, and J. DeAbate; 16 March 1957.

Paratopotypes

INHS 59305 (4); ex. TU 15275.
Percina tanasi Etnier 1976.

Etnier 1976:473, Fig. 1.

Holotype

TU 90858 (59.1 mm SL, adult male);

Little Tennessee River at Coytee

Spring, River Mile 7, Loudon County,

Tennessee; G.F. Boronow, B.F. Clark,

Jr., D.A. Etnier, R.L. Hensen, W.C.

Starnes, and B.A. Thompson; 6

November 1973.

Allotype

TU 90859 (54.6 mm SL, female).

Paratopotypes

INHS 75000 (5); [G.F. Boronow, H.T.

Carson, M.W. Clayton, D.A. Etnier,

A.F. Ingram, A.S. McDaniel, F.V.

Oakberg, J.P. Richardson, E.M. Scott,

T.J. Timmons, and S.D. Waters]; 16 August 1973.

Etheostoma tecumsehi Ceas and Page 1997.

Ceas and Page 1997:516, Fig. 1F.

Holotype

INHS 37504 (47.6 mm SL, breeding male); unnamed tributary, West Fork Pond River [Green River drainage], 6.4 km NW Fruit Hill at Johnson Mill Road, Christian County, Kentucky; P.A. Ceas [PAC 95-131]; 4 April 1995.

Paratopotypes

INHS $36033(10,37.3-53.5 \mathrm{~mm}$ SL).

INHS 32703 (12, 28.7-43.9 mm SL);

P.A. Ceas; 22 April 1994.

DONATED MATERIAL

Paratopotypes

SIUC 25126 (5, 41.0-43.5 mm SL), UT 91.4752 (5, 42.0-48.5 mm SL); both ex. INHS 32703.

UAIC 11346.01 (5, 41.7-49.6 mm SL), TU 177763 (5, 38.0-42.7 mm SL); P.A. Ceas; 26 March 1994; both ex. INHS 32400 .

UMMZ 231176 (5, 28.0-38.5 mm SL), USNM 339903 (5, 28.5-43.1 mm SL); L.M. Page and P.A. Ceas; 22 March 1990; both ex. INHS 58147.

Etheostoma wapiti Etnier and Williams 1989. Etnier and Williams 1989:989, Fig. 1.

Holotype

USNM $288069(70.8 \mathrm{~mm}$ SL, adult male); Richland Creek at County Road 4209 crossing, 11.2 air mi SSE of Pulaski, Giles County, Tennessee: 
W.C. Dickinson, D.A. Etnier, M.A.

Etnier, C.E. Louton, J.A. Louton, and W.C. Pennington; 7 June 1982.

Allotype

USNM 288070 (55 mm SL, adult female).

Paratypes

INHS 68229 (3); mouth of Indian Creek at Elk River Mile 52.5, Giles County, Tennessee; [L.M. Page]; 14 April 1985.

Etheostoma zonistium Bailey and Etnier 1988. Bailey and Etnier 1988:39, Pl. I (lower).

Holotype

UMMZ 213926 (55.5 mm SL, adult male); Leath Creek, tributary to Chambers Creek, at unnumbered county road crossing $3.2 \mathrm{~km} \mathrm{NW}$ Counce, Hardin County, Tennessee; B.F. Clark, G.A. Schuster, and E.M. Scott; 27 October 1973.

Paratypes

INHS 68218 (6); North Fork of Beason Creek (Tennessee River drainage) at co. rd. 8088 [2.5 mi. NW Crump], Hardin County, Tennessee; [B.F. Clark, G.A. Schuster, and E.M. Scott; 27 October 1973].

\section{ELASSOMATIDAE}

Elassoma alabamae Mayden 1993. Mayden 1993:2, Fig. la, b.

Holotype

UAIC 10275.01 (17.4 mm SL, adult male); Tennessee River drainage.

Alabama, Limestone County, Moss Spring and effluent run into Beaverdam Creek, $1.4 \mathrm{mi} \mathrm{N}$ of Greenbriar (T4S, R3W, Sec. 16); R.L. Mayden, B.R. Kuhajda, H.T. Boschung, T.S.

Jandebeur, and J.R. Tomelleri; 2 March 1992.

Allotype

UAIC 10275.05 (17.4 mm SL, adult female).

Paratopotypes

INHS 28324 (10, 15-20 mm SL); ex. UAIC 10275.06.

\section{ISLNH Types Missing from INHS}

\section{CYPRINIDAE}

Lythrurus atripes Jordan 1878.

Jordan 1878a:59.

Lectotype

[USNM 26295 (46.0 mm SL)]; various streams in Union and Johnson counties [restricted to Cache River, Johnson County, by Snelson and Pflieger (1975:235)], Illinois; S.A. Forbes; [July 1877; ISLNH acc. no. 43].

Remarks: Original description based on syntypic series of an unknown number of specimens measuring 2.5 to 3 inches in length. USNM lectotype originally designated by Jordan and Evermann (1896:300) and subsequently by Snelson and Pflieger (1975:235), who noted that the label with the specimen specifies Cache River. Lectotype bears ISLNH acc. no. 43 (Williams 1996), which corresponds to collections from "Cache R., Johnson Co., Illinois, July 1877 " according to the ISLNH accession catalog.

Paralectotypes

Missing: The syntypic series was originally cataloged and presumably retained (in part) at ISLNH; however, no specimens of this series were located in the INHS collection.

Taxonomic Status

= Lythrurus umbratilis cyanocephalus (Copeland in Jordan 1877c)

According to Gilbert (1978:27), this form was regarded as a subspecies of $L$. ardens by Jordan (1885:814) and as a subspecies of $L$. umbratilis by Jordan and Evermann (1896:300). Snelson and Pflieger (1975:235) placed atripes in the synonymy of Lytlirurus umbratilis (Girard 1856) and assigned it to the subspecies L. u. cyanocephalus.

Donated Material

Lectotype

[USNM 26295] (see account above).

Paralectotypes

[CAS-SU 1989 (2); collection data presumably same as for lectotype].

Remarks: CAS-SU types were located by C.R. Gilbert and bear only the 
notation "Illinois" (Snelson and Pflieger 1975).

Codoma chloristia Jordan and Brayton 1878. Jordan and Brayton 1878:21.

Lectotype

[MCZ 24380 (50.1 mm SL)]; Saluda River (Santee River basin) at Farr's Mills, W of Greenville, [Greenville County], South Carolina; D.S. Jordan, A.W. Brayton, C.H. Gilbert, and a party of students from Butler University; summer 1877.

Remarks: Gibbs (1963:522) designated the lectotype.

Paralectotypes

[ISLNH acc. no. 27533 ( 1); ? collection data same as lectotype].

Remarks: A specimen from the syntypic series was apparently deposited at ISLNH as evidenced by the accession catalog entry "Codonla chlorista Jor. (Type)." This specimen is not presently found in the INHS collection. Gilbert (1978:36) located an additional paralectotype BMNH 1880.1.21.43 (1) with collection data same as lectotype.

Taxonomic Status

$=$ Cyprinella chloristia (Jordan and Brayton 1878)

In a review of this and related forms, Gibbs (1963:522) assigned chloristia as a subspecies of Cyprinella analostana Girard 1859; however, it is currently accepted as a valid species (Page and Burr 1991; Robins et al. 1991; Mayden et al. 1992).

Phenacobius teretulus liosternus Nelson 1876. Nelson 1876:46.

Holotype

[ISLNH acc. no. 28267] (adult); small streams in McLean County [MackinawIllinois River drainage], Illinois; [1875].

Remarks: Nelson mentioned "a number of specimens of this form" in the ISLNH collection, but restricted the species description to a single "adult" herein considered the holotype by monotypy. An entry in the ISLNH accession catalog specifies "Type of Phenacobius teretulus liosternus
Nelson, McLean Co., Ill., 1875" with the annotation " $=P$. mirabilis."

Neither the holotype nor any additional specimens (= paratypes) of this form collected prior to 1877 are presently found at INHS.

Taxonomic Status

= Phenacobius mirabilis (Girard 1856)

Nelson described liosternus as a variety of Phenacobius teretulus Cope 1867. Jordan (1878a:61) placed it in synonymy with $P$. scopiferus (Cope 1871), a species whose distinctness from $P$. mirabilis (Girard 1856) was questioned by Jordan and Gilbert (1883:205) and Jordan and Evermann (1896:303). Forbes and Richardson (1909:159) included $P$. scopifera (of Cope) in the synonymy of $P$. mirabilis, finding the two nominal forms "impossible" to separate in their collections.

Notropis macrolepidotus Forbes 1885.

Forbes 1885:138.

Holotype

[ISLNH acc. no. 28379] (length 2.1

in.); Illinois [Illinois River according to Forbes (1884:76)].

Remarks: Original description based on a single specimen considered holotype by monotypy. This specimen was deposited at ISLNH as evidenced from the accession catalog entry "Notropis macrolepidotus, Forbes, type"; however, it is not presently located at INHS and presumed lost.

TAXONOMIC Status

$=$ subjective senior synonym of

Lythrurus fumeus (Evermann 1892)

Forbes (1884:76) applied the name Notropis macrolepidotus (as a nomen nudum) to "a very rare minnow, taken thus far only from the Illinois River." In its subsequent description (based on a single specimen from an unspecified locality in Illinois) Forbes (1885:138) stated: "This fish . . closely resembles Notropis atripes [= Lythrurus umbratilis], from which it differs especially in the larger scales, and in the entire absence of any blotch at the front of the base of the dorsal fin." Forbes and Richardson (1909:154) later synonymized macrolepidotus with 
Notropis umbratilis atripes $(=L . u$. cyanocephalus), but distinguished three different "varieties" among Illinois specimens. They noted the variation accordingly: "most . . . specimens have the dark blotch at base of dorsal [fin] prominent, and anal [fin] dusky in males (atripes); others . . . much fewer in number have the spot faint or obsolete (macrolepidotus); in some specimens there are distinct traces of 3 to 5 vertical bars of dusky on back portion of sides and fore part of caudal peduncle (fasciolaris?)." The name macrolepidotus remained a questionable synonym of Notropis umbratilis until Snelson (1973:168) pointed out that the original description might apply to Notropis (= Lythrurus) fumeus Evermann 1892. Snelson, however, questioned this synonymy on the basis of a statement in the original description: "scale formula 6-40-3, 19 before dorsal." Snelson interpreted Forbes' count (19) as the number of predorsal scales, which was well below his range of predorsal scale counts for both $N$. fumeus (23-37) and N. umbratilis (not given). However, Forbes' count does fall within the range of predorsal scale rows reported for $N$. fumeus $(18-27)$ by Snelson (1973:170). Distinction between "scales" and "rows" was not made in the original description and the two terms were applied somewhat indiscriminately to counts in other species described in Forbes' (1885) paper. Snelson also noted that $N$. fumeus is not currently known from the Illinois River system (where $L$. umbratilis does occur); however, its past occurrence there is conceivable (Gilbert 1978:58). In our opinion, Forbes' accounts of atripes, macrolepidotus, and fasciolaris accurately discriminated species presently recognized as Lythrurus umbratilis, L. fumeus, and $L$. fasciolaris, respectively. Because the type specimen remains lost, it seems prudent to treat macrolepidotus and fumeus as subjective synonyms and petition the International Commission to suppress the older name macrolepidotus (Art. 79 of the International Code of Zoological Nomenclature).

\section{Notropis phenacobius Forbes 1885.}

Forbes 1885:137.

Syntypes

[ISLNH ?] (10, length 2.5 in.); [Illinois River] at Peoria, [Peoria County], Illinois.

Remarks: Original description based on syntypic series of 10 specimens originally deposited in the ISLNH collection. However, through some "unaccountable misadventure" all but one were lost (Forbes and Richardson 1909:139). The remaining type was not located by Smith and Bridges (1960) and is still considered lost. Gilbert (1978:69-70) noted that six specimens labeled as questionable types of N. phenacobius (FMNH 70579) are not of the syntypic series (he identified them as Notropis stramineus (Cope 1865)).

Taxonomic Status $=$ subjective senior synonym of Hybopsis amnis (Hubbs and Greene in Hubbs 1951)

Jordan and Evermann (1896:263) synonymized $N$. phenacobius with $N$. scylla ( $=N$. stramineus), an action followed by Suttkus (1958:313). However, Forbes and Richardson (1909, 1920 [2nd ed.]) and Jordan et al. (1930:134) retained this form as a valid species apparently on the basis of B.W. Evermann's examination of the single remaining type specimen. In Forbes and Richardson (1909:139) Evermann is quoted: "In some respects this specimen resembles $N$. blennius, but is much deeper and more arched, and the head is slightly longer. We have compared it with the type of 'Cliola chlora Jordan,' which is considered a synonym of $N$. scylla [= Notropis stramineus], but it is not that species. . If you have any reason for believing that this specimen is the type of your $N$. phenacobins, I would be disposed to accept it as such and let the species stand as good." Gilbert (1978:70) also doubted the synonymy of phenacobius 
with $N$. stramineus. He demonstrated that the original description and an illustration (head only) in Forbes and Richardson (1909:138) agreed well with Notropis (= Hybopsis) amnis, a species described by Hubbs and Greene (in Hubbs 1951). Gilbert provided additional evidence to support the identity of $N$. phenacobius as a senior synonym of Hybopsis amnis. Because the type specimens remain lost, the suggested course of action is to treat the two names as subjective synonyms and petition the International Commission to suppress the senior name Notropis phenacobius (Art. 79 of the International Code of Zoological Nomenclature).

\section{CATOSTOMIDAE}

\section{Bubalichthys altus Nelson 1877.}

in Jordan 1877c:73.

Holotype

[ISLNH ?] (12 in. long); [Ohio River at] Cairo, [Alexander County], Illinois. Remarks: Original description based on one specimen in the ISLNH collection; considered the holotype by monotypy. The holotype was not found at INHS and is presumed lost.

\section{TAXONOMIC STATUS}

= Ictiobus bubalus (Rafinesque 1818)

Jordan (1877c:74) examined the holotype and considered it "certainly distinct from B. bubalus, Ag. [= Ictiobus bubalus], and still more so from $B$. [= Ictiobus] niger." Jordan (1878b:207) soon lost this distinction and relegated altus to the synonymy of Bubalichthys bubalus Agassiz 1855. This treatment was reversed in Jordan and Gilbert (1883:116), who recognized Bubalichthys altus as the "oldest tenable name, certainly belonging to the species" and placed $B$. bubalus in its synonymy. Disparity in their relative placements ended when Jordan and Evermann (1896:165) included both $B$. altus and B. bubalus in the synonymy of Ictiobus bubalus (Rafinesque 1818).
Ichthyobus cyanellus Nelson 1876.

Nelson 1876:49.

Holotype

[ISLNH acc. no. 26440]; Illinois River [between LaSalle and Pekin, Illinois].

Remarks: Nelson's original description specified a "type" from the Illinois River herein considered the holotype. This specimen was apparently deposited at ISLNH as evidenced from accession catalog entry 26440 , which states "Type of Nelson's "Ichthyobus cyanellus', Illinois River." This specimen is not presently located at INHS and is presumed lost.

Paratypes

[ISLNH ? (?)]; Illinois River, [1llinois].

[? USNM (?)]; Mississippi [River] at St. Louis; collection of D.S. Jordan.

Remarks: Original description based on "several specimens, measuring from 8 to $9 \mathrm{l} / 4$ inches in length." Nelson mentioned a "number of specimens [= paratypes] of this species" in the ISLNH collection, from the Illinois River, and in D.S. Jordan's collection, from the Mississippi River at St. Louis. None of the type material is presently located in the INHS collection; the existence of paratypes elsewhere is unknown.

TAXONOMIC STATUS

= Ictiobus bubalus (Rafinesque 1818) Jordan (1878a:66) re-identified the type specimens of Nelson's I. cyanellus as juvenile Bubalichthys bubalus of Agassiz 1855, and commented: "the specific name 'bubalus' is hardly tenable for this species, if we conceive that the bubalus of Rafinesque is an Ichthyobus." Jordan (1878a:66) temporarily adopted the name Bubalichthys cyanellus apparently to avoid its confusion with Rafinesque's I. bubalus. Jordan (1878b:206) later (and more appropriately) placed Nelson's $I$. cyanellus in synonymy with B. bubalus Agassiz 1855. Both nominal forms were eventually synonymyzed with Ictiobus bubalus (Rafinesque 1818). However, the 
relegation of Nelson's I. cyanellus (Jordan and Gilbert 1883:114) to I. bubalus preceded that of Agassiz's B. bubalus (Jordan and Evermann 1896:165) apparently because one of Nelson's type specimens was first recognized as (i.e., most closely resembled) Rafinesque's Ictiobus bubalus (Jordan and Gilbert 1883:114). The appearance of Ichthyobus cyanellus in the synonymy of Ictiobus cyprinella in Jordan and Evermann (1896:164) is interpreted as an orthographic error because it is inconsistent with both previous and subsequent placements of this form.

\section{Ichthyobus ischyrus Nelson 1877.}

in Jordan 1877c:73.

Syntypes

[ISLNH ?] (?, 11 1/2 in. long);

Mackinaw Creek [= River] in central Illinois, a tributary of Illinois River [near Peoria, Tazewell County].

Remarks: Nelson's description appears to be based on a single specimen; however, it is followed by Jordan's statement "Type specimens $111 / 2$ inches long. . . Several younger specimens also in State Collection [ISLNH]." Later, Jordan (1878b:215) mentioned his examination of "the type of I. ischyrus" in the ISLNH collection and referred to the type locality as "near Peoria." None of the type material is found in the INHS collection.

Taxonomic Status

= Ictiobus bubalus (Rafinesque 1818) Upon reexamining the type specimen, Jordan (1878b:215) relegated

I. ischyrus to the synonymy of Ictiobus bubalus (Rafinesque 1818). The name I. ischyrus subsequently disappeared from the literature.

Donated Material

? Syntype(s)

[USNM 20774] (?); Illinois River at Peoria [Peoria County, Illinois]; S.A. Forbes.

Remarks: Jordan (1878b:217) listed the above specimen(s) of I. ischyrus with the annotation "very large; typical of bubalus." The specimen(s) may be of the type material identified by Nelson: however, the status of this lot at USNM is unknown and it is not generally considered to be a type lot (C. Gilbert, pers. comm.).

\section{PERCIDAE}

Poecilichthys asprigenis Forbes 1878. in Jordan 1878a:41.

Syntypes

[ISLNH ?] (14, length $35-45 \mathrm{~mm}$ ); small creek near Pekin, [Tazewell County], Illinois.

Remarks: Original description based on syntypic series of 14 specimens, none of which were found at INHS.

Taxonomic Status

= Etheostoma (Oligocephahtus)

asprigene (Forbes 1878)

Bailey (1951:195) referred asprigene to the genus Etheostoma. Using available names to group species into subgenera, Bailey and Gosline (1955:17) assigned asprigene to Oligocephalus, a subgenus later diagnosed by Bailey and Richards (1963:3) and Page (1981:39).

Donated Material

Syntypes

[CAS-SU 2201 (2, 38-39 mm SL); collection data same as ISLNH syntypes].

Remarks: CAS syntypes located by Böhlke (1953:74) and measured by Collette and Knapp (1967).

Boleosoma camurum Forbes 1878. in Jordan 1878a:40.

[ISLNH ?] (?, length $45-50 \mathrm{~mm}$, also given as $35-50 \mathrm{~mm})$; several localities in Illinois ... Cache River and Clear Creek, Union County; Johnson County; Pekin [Tazewell County].

Remarks: Original description based on syntypic series of an unknown number of specimens. Smith and Bridges (1960:254) recovered a jar with three lots of darters and a label stating "? types of Boleosoma camurum Forbes." The three collections are as follows: INHS 59302, 6 specimens 
from Peoria Lake, Peoria County, Illinois, 23 October 1879, ISLNH acc. no. 181; INHS 59303, 1 specimen from the Ohio River, Cairo, Alexander County, Illinois, 23 September 1879; ISLNH acc. no. 189; and INHS 59304, 20 specimens from the Little Wabash River, Effingham, Effingham County, Illinois; June 1877; ISLNH acc. no. 44. The specimens are identified as Etheostoma chlorosomum (Hay 1881) and are in fair to poor condition. No mention is made of the above localities in the original description, and there is no indication on the original labels or in the accession catalog that these specimens are types. Only one of the three lots (INHS 59304) was collected prior to the date of description; however, these specimens (13.4-19.5 $\mathrm{mm} \mathrm{SL}$ ) are much smaller than what Forbes (in Jordan 1878a:40) indicated (35-50 mm) in his description of B. camurum. Smith and Bridges (1960:254) did not consider any of this material to be of the original syntypic series and presumed the ISLNH types lost.

TAXONOMic Status

\section{= Etheostoma (Vaillantia) \\ chlorosomum (Hay 1881)}

The specific name chlorosomum Hay 1881 is applied to this form because camurum Forbes 1878 is preoccupied in Etheostoma by Poecilichthys camurus Cope 1870. Bailey and Gosline (1955:15) listed chlorosomum in the subgenus Boleosoma, which was subsequently diagnosed by Cole (1967). Cole therein removed chlorosomum from Boleosoma and diagnosed the subgenus Vaillantia Jordan and Brayton 1878 for this species.

Donated Material

Syntypes

[CAS-SU 1683 (1, 44 mm SL, female); Illinois].

[MCZ 25053 (1, 38 mm SL, female); Peoria Lake, Illinois].

[UMMZ 187505 (1, 39 mm SL);

Pekin, Illinois; ex. IU 506, then IU 4707].

[USNM 23455 ( 1, 44 mm SL, female); Illinois River, Illinois].
[USNM 27894 (2, $39 \mathrm{~mm} \mathrm{SL}$, fe males); Peoria Lake, Illinois; S.A. Forbes; 27 October 1878; ISLNH acc. no. 211].

Remarks: Material identified as syntypes and measured by Collette and Knapp (1967:14); collection data presumably based on information housed with the specimens. Attention is called to specimens from "Peoria Lake," a locality on the Illinois River not mentioned in the original description. Pekin is about 10 river miles downstream of Peoria Lake and the two localities are generally recorded separately in the ISLNH accession catalog. ISLNH catalog entry (acc. no. 211 ) indicates USNM 27894 specimens were collected 27 October 1878 from "Lake, Peoria."

Etheostoma phoxocephalum Nelson 1876. Nelson 1876:35.

? Syntypes

[ISLNH acc. no. 28271] (?); western part of state [Illinois], rather common in the Illinois [River] and its tributaries.

Remarks: Described from a syntypic series of an unknown number of specimens, none of which were found at INHS. The ISLNH accession entry for 28271 reads "Type(?) of Hadropterus phoxocephalus, Nelson, Illinois, 1877."

TAXONOMIC Status

= Percina (Swainia) phoxocephala

(Nelson 1876)

Bailey and Gosline (1955:13) assigned phoxocephala to the subgenus Swainia of the genus Percina. The subgenus Swainia was subsequently diagnosed by Page (1974:83).

Donated Material

Syntypes

[UMMZ 187504] $(2,49-52 \mathrm{~mm}$ SL, males); Illinois; S.A. Forbes; ex. IU 499, then IU 4702.

Remarks: This material was located and measured by Collette and Knapp (1967:36), who noted that the apparent syntypes were not labeled as such nor listed in the $\mathrm{IU}$ catalog as types.

Collection data presumably based on information housed with specimens. 


\section{COTTIDAE}

Cottopsis ricei Nelson 1876.

Nelson 1876:40.

Holotype

? (?); shore of Lake Michigan near

Evanston, [Cook County], Illinois; F.L.

Rice.

Remarks: Original description based on a single specimen considered holotype by monotypy. This specimen was not found at INHS and its original deposition at ISLNH is questionable. Forbes and Richardson (1909:328) mentioned that access to Nelson's type specimen was lacking for their preparation of this species' account in the The Fishes of Illinois.

TAXONOMIC STATUS $=$ Cottus ricei $($ Nelson 1876) Jordan and Evermann (1898:19411942) placed Cottopsis Girard 1850 and several other genera of sculpins in the synonymy of Cottus Linnæus 1758. 


\section{Literature Cited}

Agassiz, L. 1853. Recent researches of Prof. Agassiz. American Journal of Science and Arts 16:135-136.

Agassiz, L. 1854. Notice of a collection of fishes from the southern bend of the Tennessee River, in the state of Alabama. American Journal of Science and Arts 17(series 2):297308, 353-365.

Agassiz, L. 1855. Synopsis of the ichthyological fauna of the Pacific slope of North America, chiefly from the collections made by the U.S. Expl. Exped., under the command of Capt. C. Wilkes, with recent additions and comparisons with eastern types. American Journal of Science and Arts 19(series 2):186-231.

Armbruster, J.W., and L.M. Page. 1996. Redescription of Aphanotorulus (Teleostei: Loricariidae) with description of one new species, A. ammophilus, from the Río Orinoco basin. Copeia 1996(2):379-389.

Bailey, R.M. 1938. A systematic revision of the centrarchid fishes, with a discussion of their distribution, variations, and probable interrelationships. Ph.D. dissertation, University of Michigan, Ann Arbor. 256 pp.

Bailey, R.M. 1951. A check-list of the fishes of Iowa, with keys for identification. Pages 187-237 in J.R. Harlan and E.B. Speaker, eds. Iowa fish and fishing. Iowa State Conservation Commission. 237 pp.

Bailey, R.M. 1959. Distribution of the American cyprinid fish Notropis anogenus. Copeia 1959(2): 119-123.

Bailey, R.M., and F.B. Cross. 1954. River sturgeons of the American genus Scaphirhynchus: characters, distribution, and synonymy. Papers of the Michigan Academy of Science, Arts, and Letters 39:169-208.

Bailey, R.M., and D.A. Etnier. 1988. Comments on the subgenera of darters (Percidae) with descriptions of two new species of Etheostoma (Ulocentra) from southeastern
United States. Miscellaneous Publications Museum of Zoology, University of Michigan 175:iv + 1-48.

Bailey, R.M., and W.A. Gosline. 1955. Variation and systematic significance of vertebral counts in the American fishes of the family Percidae. Miscellaneous Publications Museum of Zoology, University of Michigan 93:1-44.

Bailey, R.M., and W.J. Richards. 1963. Status of Poecilichthys hopkinsi Fowler and Etheostoma trisella, new species, percid fishes from Alabama, Georgia, and South Carolina. Occasional Papers of the Museum of Zoology, University of Michigan 630:1-21.

Bailey, R.M., and H.W. Robison. 1978. Notropis hubbsi, a new cyprinid fish from the Mississippi River basin, with comments on Notropis welaka. Occasional Papers of the Museum of Zoology, University of Michigan 683:1-21.

Baird, S.F., and C. Girard. 1853. Descriptions of new species of fishes collected by Mr. John H. Clark, on the U.S. and Mexican Boundary Survey, under Lt. Col. Jas. D. Graham. Proceedings of the Academy of Natural Sciences of Philadelphia 6:387-392.

Bănărescu, P. 1964. Fauna republicii populare Romine (Pisces-Osteichthyes). Editura Academiei Republicii Populare Romine, Bucharest, Romania, 13:1-962.

Bauer, B.H., D.A. Etnier, and N.M. Burkhead. 1995. Etheostoma (Ulocentra) scotti (Osteichthyes: Percidae), a new darter from the Etowah River system in Georgia. Bulletin Alabama Museum of Natural History 17:1-16.

Beckham, E.C., III. 1980. Percina gymnocephala, a new percid fish of the subgenus Alvordius, from the New River in North Carolina, Virginia, and West Virginia. Occasional Papers of the Museum of Zoology, Louisiana State University 57:1-11. 
Berg, L.S. 1904. Zur systematik der Acipenseriden. Zoologischer Anzeiger, Bd. 27, Nr. 22:665-667.

Berg, L.S. 1911. Faune de la Russie et des pays limitrophes. Poissons (Marsipobranchii et Pisces), Vol. 1. St. Petersburg. 337 pp., 8 pls., 1 map.

Berg, L.S. 1948. Fresh water fishes of the U.S.S.R. and adjoining countries, Vol. I. Academy of Sciences of the U.S.S.R., Moscow. 466 pp., 281 figs.

Böhlke, J.E. 1953. A catalogue of the type specimens of recent fishes in the Natural History Museum of Stanford University. Stanford Ichthyological Bulletin 5(1):1-168.

Boltz, J.M., and J.R. Stauffer, Jr. 1993. Systematics of Aphredoderus sayanus (Teleostei: Aphredoderidae). Copeia 1993(1):81-98.

Braasch, M.E., and R.L. Mayden. 1985. Review of the subgenus Catonotus (Percidae) with descriptions of two new darters of the Etheostoma squamiceps species group. Occasional Papers of the Museum of Natural History, University of Kansas 119:1-83.

Braasch, M.E., and L.M. Page. 1979. Systematic studies of darters of the subgenus Catonotus (Percidae), with the description of a new species from Caney Fork, Tennessee. Occasional Papers of the Museum of Natural History, University of Kansas 78:1-10.

Burr, B.M. 1977. The bantam sunfish, Lepomis symmetricus: systematics and distribution, and life history in Wolf Lake, Illinois. Illinois Natural History Survey Bulletin 31(10):437-465.

Burr, B.M. 1979. Systematics and life history aspects of the percid fish Etheostoma blennius with description of a new subspecies from Sequatchie River, Tennessee. Copeia 1979(2):191-203.

Burr, B.M., and R.C. Cashner. 1983. Campostoma pauciradii, a new cyprinid fish from southeastern United States, with a review of related forms. Copeia 1983(1):101-116.
Burr, B.M., and L.M. Page. 1987. Philip Wayne Smith 1921-1986. Copeia 1987(3):839840.

Burr, B.M., and L.M. Page. 1993. A new species of Percina (Odontopholis) from Kentucky and Tennessee with comparisons to Percina cymatotaenia (Teleostei: Percidae). Bulletin Alabama Museum of Natural History 16:15-28.

Campos, H.H., and C. Hubbs. 1973. Taxonomic implications of the karyotype of Opsopoeodus emiliae. Copeia 1973(1):161163.

Ceas, P.A., and L.M. Page. 1996.

Chaetostoma yurubiense (Teleostei:

Siluriformes), a new species of loricariid catfish from the Aroa, Urama, and Yaracuy River systems in Venezuela. Copeia 1996(3):671-677.

Ceas, P.A., and L.M. Page. 1997. Systematic studies of the Etheostoma spectabile complex (Percidae; Subgenus Oligocephalus), with descriptions of four new species. Copeia 1997(3):496-522.

Coburn, M.M., and T.M. Cavender. 1992. Interrelationships of North American cyprinid fishes. Pages 328-373 in R.L. Mayden, ed. Systematics, historical ecology, and North American freshwater fishes. Stanford University Press, Stanford, California. xxvi + 969 pp.

Cole, C.F. 1967. A study of the eastern johnny darter, Etheostoma olmstedi Storer (Teleostei, Percidae). Chesapeake Science 8:28-51.

Collette, B.B., and L.W. Knapp. 1967. Catalog of type specimens of the darters (Pisces, Percidae, Etheostomatini). Proceedings of the United States National Museum 119(3550): $1-88$.

Cope, E.D. 1865. Partial catalogue of the cold-blooded vertebrata of Michigan. Pt. 1. Proceedings of the Academy of Natural Sciences of Philadelphia 16(1864):276-285.

Cope, E.D. 1867. [Description of a new genus of cyprinoid fishes from Virginia]. Proceedings of the Academy of Natural Sciences of Philadelphia 19:95-97. 
Cope, E.D. 1870 . On some etheostomine perch from Tennessee and North Carolina. Proceedings of the American Philosophical Society 11:261-270.

Cope, E.D. 1871. Report on the reptiles and fishes obtained by the naturalists of the expedition. Pages 432-442 in F.V. Hayden, ed. Second [fourth] annual report, U.S. Geological Survey of Wyoming and portions of contiguous territories.

Cuvier, G., and A. Valenciennes. 1831. Histoire naturelle des poissons. Vol. 7. F.G. Levrault, Paris, France. 531 pp.

Etnier, D.A. 1976. Percina (Imostoma) tanasi, a new percid fish from the Little Tennessee River, Tennessee. Proceedings of the Biological Society of Washington 88(44):469-488.

Etnier, D.A., and R.M. Bailey. 1989. Etheostoma (Ulocentra) flavum, a new darter from the Tennessee and Cumberland River drainages. Occasional Papers of the Museum of Zoology, University of Michigan 717:1-24.

Etnier, D.A., and R.E. Jenkins. 1980. Noturus stanauli, a new madtom catfish (Ictaluridae) from the Clinch and Duck rivers, Tennessee. Bulletin Alabama Museum of Natural History 5:17-22.

Etnier, D.A., and W.C. Starnes. 1993. The fishes of Tennessee. University of Tennessee Press, Knoxville. xiv +681 pp.

Etnier, D.A., and J.D. Williams. 1989. Etheostoma (Nothonotus) wapiti (Osteichthyes: Percidae), a new darter from the southern bend of the Tennessee River system in Alabama and Tennessee. Proceedings of the Biological Society of Washington 102(4):987-1000.

Evermann, B.W. 1892. A report upon investigations made in Texas in 1891. Bulletin of the United States Fish Commission 11:61-90.

Forbes, S.A. 1881. A rare fish in Illinois. The American Naturalist 15(1):232-233.

Forbes, S.A. 1882. The blind cave fishes and their allies. The American Naturalist 16(1):1-5.
Forbes, S.A. 1884. A catalogue of the native fishes of Illinois. Pages 60-89 in Report of the Illinois State Fish Commission, to the Governor of Illinois.

Forbes, S.A. 1885. Description of new Illinois fishes. Bulletin of the Illinois State Laboratory of Natural History 2(2):135-139.

Forbes, S.A., and R.E. Richardson. 1905. On a new shovelnose sturgeon from the Mississippi River. Bulletin of the Illinois State Laboratory of Natural History 7(4):37-44, 4 pls.

Forbes, S.A., and R.E. Richardson. [1909]. The fishes of Illinois. Illinois State Laboratory of Natural History. cxxxi +357 pp.

Forbes, S.A., and R.E. Richardson. 1920. The fishes of Illinois, 2nd ed. Illinois Natural History Survey. cxxxvi $+357 \mathrm{pp}$.

Fowler, H.W. 1941. A collection of freshwater fishes obtained in Florida, 1939-1940, by Francis Harper. Proceedings of the Academy of Natural Sciences of Philadelphia 92(1940):227-244.

Gibbs, R.H., Jr. 1963. Cyprinid fishes of the subgenus Cyprinella of Notropis. The Notropis whipplei-analostanus-chloristius complex. Copeia 1963(3):511-528.

Gilbert, C.H. 1884. A list of fishes collected in the East Fork of White River, Indiana, with descriptions of two new species. Proceedings of the United States National Museum 7(13):199-205.

Gilbert, C.H. 1891. Report of explorations made in Alabama during 1889, with notes on the fishes of the Tennessee, Alabama, and Escambia rivers. Bulletin of the United States Fish Commission 9:143-159.

Gilbert, C.R. 1964. The American cyprinid fishes of the subgenus Luxilus (Genus Notropis). Bulletin of the Florida State Museum, Biological Sciences 8(2):95-194.

Gilbert, C.R. 1978. Type catalogue of the North American cyprinid fish genus Notropis. Bulletin of the Florida State Museum, Biological Sciences 23(1):1-104. 
Gilbert, C.R., and R.M. Bailey. 1972. Systematics and zoogeography of the American cyprinid fish Notropis (Opsopoeodus) emiliae. Occasional Papers of the Museum of Zoology, University of Michigan 664:1-35.

Gilliams, J. 1824. Description of a new species of fish of the Linnean genus Perca. Journal of the Academy of Natural Sciences of Philadelphia 4:80-82.

Girard, C.F. 1850. A monograph of the freshwater Cottus of North America. American Association for the Advancement of Science Proceedings for 1849 2:409-411.

Girard, C.F. 1856. Researches upon the cyprinoid fishes inhabiting the fresh waters of the United States of America, west of the Mississippi Valley, from specimens in the Museum of the Smithsonian Institution. Proceedings of the Academy of Natural Sciences of Philadelphia 8(5): 165-213.

Girard, C.F. 1859. Ichthyological notices. Proceedings of the Academy of Natural Sciences of Philadelphia 11:56-68.

Hay, O.P. 1881. On a collection of fishes from eastern Mississippi. Proceedings of the United States National Museum 3(179):488-515.

Heckel, J. 1836. Scaphirhynchus, eine neue Fischgattung aus der Ordnung der Chondropterygier mit freien Kiemen.

Zoologisch Abhandlungen Annalen Wiener Museums Naturgeschichte, Bd. 1:68-78, 1 pl.

Howard, L.O. 1932. Biographical memoir of Stephen Alfred Forbes 1844-1930. National Academy of Sciences of the United States of America Biological Memoirs 15(1):1-54.

Hubbs, C.L. 1926. A check-list of the fishes of the Great Lakes and tributary waters, with nomenclatorial notes and analytical keys. Miscellaneous Publications Museum of Zoology, University of Michigan 15:3-77, 4 pls.

Hubbs, C.L. 1951. Notropis ammis, a new cyprinid fish of the Mississippi fauna, with two subspecies. Occasional Papers of the Museum of Zoology, University of Michigan 530:1-30, I pl.

Hubbs, C.L., and R.M. Bailey. 1952. Identification of Oxygeneum pulverulentum Forbes, from Illinois, as a hybrid cyprinid fish. Papers of the Michigan Academy of Science, Arts and Letters 37(1951):143-152, 1 pl.

Hubbs, C.L., and K. Bonham. 1951. New cyprinid fishes of the genus Notropis from Texas. Texas Journal of Science 3(1):91-110.

Hubbs, C.L., and L.C. Hubbs. 1932. Experimental verification of natural hybridization between distinct genera of sunfishes. Papers of the Michigan Academy of Science, Arts and Letters 15:427-437.

Hubbs, C.L., and K.F. Lagler. 1947. Fishes of the Great Lakes region. Cranbrook Institute of Science Bulletin No. 26. xi +186 pp.

Hubbs, C.L., and K.F. Lagler. 1958. Fishes of the Great Lakes region. 2d ed. Cranbrook Institute of Science Bulletin No. 26. xiii +213 pp.

Hubbs, C.L., and R.R. Miller. 1977. Six distinctive cyprinid fish species referred to Dionda inhabiting segments of the Tampico Embayment drainage of Mexico. Transactions of the San Diego Society of Natural History 18(17):268-335.

Hubbs, C.L., and A.I. Ortenburger. 1929. Fishes collected in Oklahoma and Arkansas in 1927. Publications of the University of Oklahoma Biological Survey 1(3):47-112.

Isbrücker, I.J.H. 1979. Descriptions préliminaires de nouveaux taxa de la famille des Loricariidae. Revue Française d'Aquariologie [1978] 5(4):86-116.

Isbrücker, I.J.H. 1980. Classification and catalogue of the mailed Loricariidae (Pisces, Siluriformes). Verslagen en Technische Gegevens No. 22, Instituut voor Taxonomische Zoölogie (Zoölogisch Museum), Universiteit van Amsterdam. 181 pp.

Jenkins, R.E., and N.M. Burkhead. 1994. Freshwater fishes of Virginia. American 
Fisheries Society, Bethesda, Maryland. xxiii + $1079 \mathrm{pp}$.

Jordan, D.S. 1877a. Revision of genera and other ichthyological matters. Proceedings of the Academy of Natural Sciences of Philadelphia 29:76-82.

Jordan, D.S. 1877b. Contributions to North American ichthyology. II.A.-Notes on Cottidae, Etheostomatidae, Percidae, Centrarchidae, Aphododeridae, Umbridae, Esocidae, Dorysomatidae, Cyprinidae, Catostomidae, and Hyodontidae, with revisions of the genera and descriptions of new or little known species. Bulletin of the United States National Museum 10:1-68.

Jordan, D.S. 1877c. On the fishes of northern Indiana. Proceedings of the Academy of Natural Sciences of Philadelphia 29:42-76.

Jordan, D.S. 1878a. A catalogue of the fishes of Illinois. Bulletin of the Illinois State Laboratory of Natural History 1(2):37-70.

Jordan, D.S. 1878b. A synopsis of the Family Catostomidae. Bulletin of the United States National Museum 12:97-237.

Jordan, D.S. 1885. A catalogue of the fishes known to inhabit the waters of North America, north of the Tropic of Cancer, with notes on the species discovered in 1883 and 1884. Annual Report of the United States Commission of Fish and Fisheries 13[1885]:787-973.

Jordan, D.S. 1929a. Manual of the vertebrate animals of the northeastern United States inclusive of marine species, 13th ed. World Book Company, Yonkers-on-Hudson, New York. xxxi +446 pp.

Jordan, D.S. 1929b. Forbesichthys for Forbesella. Science 70(1803):68.

Jordan, D.S., and A.W. Brayton. 1877. On Lagochila, a new genus of catostomid fishes. Proceedings of the Academy of Natural Sciences of Philadelphia 29:280-283.

Jordan, D.S., and A.W. Brayton. 1878. Contributions to North American ichthyology, based primarily on the collections of the United
States National Museum. III.A.-On the distribution of the fishes of the Alleghany region of South Carolina, Georgia, and Tennessee, with descriptions of new or little known species. Bulletin of the United States National Museum 12:1-95.

Jordan, D.S., and B.W. Evermann. 1896. The fishes of North and Middle America: a descriptive catalogue of the species of fish-like vertebrates found in the waters of North America, north of the Isthmus of Panama. Part 1. Bulletin of the United States National Museum 47(1):lx + 1240 pp.

Jordan, D.S., and B.W. Evermann. 1898. The fishes of North and Middle America: a descriptive catalogue of the species of fish-like vertebrates found in the waters of North America, north of the Isthmus of Panama. Part 2. Bulletin of the United States National Museum 47(2):xxx, 1241-2183.

Jordan, D.S., and B.W. Evermann. 1927. New genera and species of North American fishes. Proceedings of the California Academy of Sciences, Fourth Series, 16(15):501-507.

Jordan, D.S., B.W. Evermann, and H.W. Clark. 1930. Check list of the fishes and fishlike vertebrates of North and Middle America north of the northern boundary of Venezuela and Columbia. Report of the United States Commissioner of Fisheries (1928):1-670.

Jordan, D.S., and C.H. Gilbert. 1883. Synopsis of the fishes of North America. Bulletin of the United States National Museum 16[1882]: lvi +1018 pp.

Lachner, E.A., and R.E. Jenkins. 1967. Systematics, distribution, and evolution of the chub genus Nocomis (Cyprinidae) in the southwestern Ohio River basin, with the description of a new species. Copeia 1967(3):557-580.

Large, T. [1903]. A list of the native fishes of Illinois, with keys. Appendix to Report of the State Board of Fish Commissioners for September 30, 1900 to October 1, 1902. $30 \mathrm{pp}$.

Lee, D.S., C.R. Gilbert, C.H. Hocutt, R.E. Jenkins, D.E. McAllister, and J.R. Stauffer, Jr. 
1980 (et seq.). Atlas of North American freshwater fishes. North Carolina State Museum of Natural History, Raleigh. $x+854$ pp.

LeSueur. 1833. Apltredoderus, Pages ix, 445 in $\mathrm{G}$. Cuvier and A. Valenciennes, eds. Histoire naturelle des poissons. F.G. Levrault, Paris, France.

Leviton, A.E., R.H. Gibbs, Jr., E. Heal, and C.E. Dawson. 1985. Standards in herpetology and ichthyology: Part I, standard symbolic codes for institutional resource collections in herpetology and ichthyology. Copeia 1985(3):802-832.

Linnæus, C. 1758. Systema naturae per regna tria naturae, secundum classes, ordines, genera, species cum characteribus, differentiis, synonymis, locis. Editio decima, reformata, Tom. I. Laurentii Salvii, Holmiae. 824 pp.

Matthews, W.J. 1987. Geographic variation in Cyprinella lutrensis (Pisces: Cyprinidae) in the United States, with notes on Cyprinella lepida. Copeia 1987(3):616-637.

Mayden, R.L. 1988. Systematics of the Notropis zonatus species group, with description of a new species from the interior highlands of North America. Copeia 1988(1):153173.

Mayden, R.L. 1989. Phylogenetic studies of North American minnows, with emphasis on the genus Cyprinella (Teleostei:

Cypriniformes). University of Kansas Museum of Natural History Miscellaneous Publication 80. $189 \mathrm{pp}$.

Mayden, R.L. 1993. Elassoma alabanae, a new species of pygmy sunfish endemic to the Tennessee River drainage of Alabama (Teleostei: Elassomatidae). Bulletin Alabama Museum of Natural History 16:1-14.

Mayden, R.L., B.M. Burr, L.M. Page, and R.R. Miller. 1992. The native freshwater fishes of North America. Pages 827-863 in R.L. Mayden, ed. Systematics, historical ecology, and North American freshwater fishes. Stanford University Press, Stanford, California. xxvi +969 pp.
Mayden, R.L., and B.R. Kuhajda. 1989. Systematics of Notropis cahabae, a new cyprinid fish endemic to the Cahaba River of the Mobile Basin. Bulletin Alabama Museum of Natural History 9:1-16.

McPhail, J.D., and C.C. Lindsey. 1970.

Freshwater fishes of northwestern Canada and Alaska. Fisheries Research Board of Canada Bulletin 173:1-381.

Meinken, H. 1937. Beiträge zur fischfauna der mittleren Paraná. III. Blätter für Aquarien- und Terrarienkunde, 48(4):73-80.

Morris, M.A., and L.M. Page. 1981. Variation in western logperches (Pisces: Percidae), with description of a new subspecies from the Ozarks. Copeia 1981(1):95-108.

Nelson, E.W. 1876. A partial catalogue of the fishes of Illinois. Bulletin of the Illinois State Laboratory of Natural History 1(1):33-52.

Nelson, J.S. 1994. Fishes of the world, 3rd ed. John Wiley \& Sons, Inc., New York. xvii + $600 \mathrm{pp}$.

NEODAT WWW site (gopher:// fowler.acnatsci.org/). 13 September 1996.

Nielsen, J.G., and M.E. Retzer. 1994. Two new bathyl Neobythites spp. from the Caribbean Sea (Pisces, Ophidiidae). Copeia 1994(4):992-995.

Olund, L.J., and F.B. Cross. 1961. Geographic variation in the North American cyprinid fish, Hybopsis gracilis. University of Kansas Publications, Museum of Natural History 13(7):323-348.

Page, L.M. 1974. The subgenera of Percina (Percidae: Etheostomatini). Copeia 1974(1): 66-86.

Page, L.M. 1981. The genera and subgenera of darters (Percidae, Etheostomatini). Occasional Papers of the Museum of Natural History, University of Kansas 90:1-69.

Page, L.M. 1983. Handbook of darters. TFH Publications, Inc., Neptune City, New Jersey. $271 \mathrm{pp}$. 
Page, L.M., and E.C. Beckham. 1987. Notropis rupestris, a new cyprinid from the middle Cumberland River system, Tennessee, with comments on variation in Notropis heterolepis. Copeia 1987(3):659-668.

Page, L.M., and M.E. Braasch. 1976. Systematic studies of darters of the subgenus

Catonotus (Percidae), with the description of a new species from the lower Cumberland and Tennessee River systems. Occasional Papers of the Museum of Natural History, University of Kansas 60:1-18.

Page, L.M., and M.E. Braasch. 1977. Systematic studies of darters of the subgenus Catonotus (Percidae), with the description of a new species from the Duck River system. Occasional Papers of the Museum of Natural History, University of Kansas 63:1-18.

Page, L.M., and B.M. Burr. 1982. Three new species of darters (Percidae, Etheostoma) of the subgenus Nanostoma from Kentucky and Tennessee. Occasional Papers of the Museum of Natural History, University of Kansas 101:120.

Page, L.M., and B.M. Burr. 1991. A field guide to freshwater fishes of North America north of Mexico. Houghton Mifflin Company, Boston. xii +432 pp.

Page, L.M., P.A. Ceas, D.L. Swofford, and D.G. Buth. 1992. Evolutionary relationships within the Etheostoma squamiceps complex (Percidae; Subgenus Catonotus) with descriptions of five new species. Copeia 1992(3):615646.

Page, L.M., and C.E. Johnston. 1990. The breeding behavior of Opsopoeodus emiliae (Cyprinidae) and its phylogenetic implications. Copeia 1990(4):1176-1180.

\section{Pallas, P.S. 1771-1776. Reise durch} verschiedene Provinzen des Russischen Reichs. Kaiserlich Akademie der Wissenschaften erschienenen Ausgabe, St. Petersburg. 504 pp.

Poss, S.G., and B.B. Collette. 1995. Second survey of fish collections in the United States and Canada. Copeia 1995(1):48-70.
Putnam, F.W. 1863. List of the fishes sent by the museum to different institutions, in exchange for other specimens, with annotations. Bulletin of the Museum of Comparative Zoology 1(1):2-16.

Putnam, F.W. 1872. The blind fishes of Mammoth Cave and their allies. The American Naturalist 6(1):6-30.

Rafinesque, C.S. 1818. Description of two new genera of North American fishes, Opsanus and Notropis. American Monthly Magazine and Critical Review 2(3):203-204.

Rafinesque, C.S. 1819. Prodrome de 70 nouveaux genres d'animaux découverts dans l'intérieur des États-Unis d'Amérique, durant l'année 1818. Journal de Physique, de Chimie, d'Histoire Naturelle et des Arts 88:417-429.

Rafinesque, C.S. 1820. Ichthyologia Ohiensis, or natural history of the fishes inhabiting the River Ohio and its tributary streams, preceded by a physical description of the Ohio and its branches. W.C. Hunt, Lexington, Kentucky. 90 pp.

Retzer, M.E., and L.M. Page. 1997.

Systematics of the stickcatfishes, Farlowella Eigenmann \& Eigenmann (Pisces,

Loricariidae). Proceedings of the Academy of Natural Sciences of Philadelphia 147:33-88.

Richardson, J. 1836. Fauna Boreali-Americana; or the zoology of the northern parts of British America: part third The fish. Richard Bentley, London. 327 pp.

Richardson, R.E. 1904. A review of the sunfishes of the current genera Apomotis, Lepomis, and Eupomotis, with particular reference to the species found in Illinois. Bulletin of the Illinois State Laboratory of Natural History 7(3):27-35.

Ride, W.D.L., C.W. Sabrosky, G. Bernardi, and R.V. Melville, eds. International code of zoological nomenclature, 3rd ed., adopted by the XX General Assembly of the International Union of Biological Sciences. 1985. University of California Press, Berkeley. 338 pp. 
Riggs, C.D., and G.A. Moore. 1951. Some new records of paddlefish and sturgeon for Oklahoma. Proceedings of the Oklahoma Academy of Sciences 1949:16-18.

Robins, C.R., R.M. Bailey, C.E. Bond, J.R. Brooker, E.A. Lachner, R.N. Lea, and W.B. Scott. 1991. Common and scientific names of fishes from the United States and Canada, 5th ed. American Fisheries Society Special Publication 20, Bethesda, Maryland. 183 pp.

Schrenkeisen, R.M. 1938. Field book of freshwater fishes of North America north of Mexico. J.T. Nichols and F.R. LaMonte, eds. G.P. Putnam's Sons, New York. xii +312 pp.

Simons, A.M. 1992. Phylogenetic relationships of the Boleosoma species group (Percidae: Etheostoma). Pages 268-292 in R.L. Mayden, ed. Systematics, historical ecology, and North American freshwater fishes. Stanford University Press, Stanford, California. xxvi + 969 pp.

Smith, P.W. 1979. The fishes of Illinois. University of Illinois Press, Urbana. xxix + 314 pp.

Smith, P.W., and D.W. Bridges. 1960. Ichthyological type specimens extant from the old Illinois State Laboratory of Natural History. Copeia 1960(3):253-254.

\section{Snelson, F.F., Jr. 1971. Notropis}

mekistocholas, a new herbivorous cyprinid fish endemic to the Cape Fear River basin, North Carolina. Copeia 1971(3):449-462.

Snelson, F.F., Jr. 1973. Systematics and distribution of the ribbon shiner, Notropis fumeus (Cyprinidae), from the central United States. The American Midland Naturalist 89(1):166-191.

Snelson, F.F., Jr., and W.L. Pflieger. 1975. Redescription of the redfin shiner, Notropis umbratilis, and its subspecies in the central Mississippi River basin. Copeia 1975(2):231249.

Suttkus, R.D. 1958. Status of the nominal cyprinid species Moniana deliciosa Girard and Cyprinella texana Girard. Copeia 1958(4):307318.
Suttkus, R.D., and R.C. Cashner. 1981. A new species of cyprinodontid fish, Genus Fundulus (Zygonectes), from Lake Pontchartrain tributaries in Louisiana and Mississippi. Bulletin Alabama Museum of Natural History 6:1-17.

Suttkus, R.D., and G.H. Clemmer. 1968. Notropis edwardraneyi, a new cyprinid fish from the Alabama and Tombigbee River systems and a discussion of related species. Tulane Studies in Zoology and Botany 15(1):18-39.

Suttkus, R.D., and D.A. Etnier. 1991. Etheostoma tallapoosae and E. brevirostrum, two new darters, subgenus Ulocentra, from the Alabama River drainage. Tulane Studies in Zoology and Botany 28(1): 1-24.

Suttkus, R.D., B.A. Thompson, and H.L. Bart, Jr. 1994. Two new darters, Percina (Cottogaster), from the southeastern United States, with a review of the subgenus. Occasional Papers Tulane University Museum of Natural History 4:1-46.

Swift, C.C. 1970. A review of the eastern North American cyprinid fishes of the Notropis texanus species group (subgenus Alburnops), with a description of the subgenus Hydrophlox, and materials for a revision of the subgenus Alburnops. Ph.D. dissertation, Florida State University, Tallahassee. 515 pp.

Swofford, D.L. 1982. Genetic variability, population differentiation, and biochemical relationships in the family Amblyopsidae. M.S. dissertation, Eastern Kentucky University, Richmond. 193 pp.

Taylor, W.R. 1969. A revision of the catfish genus Noturus Rafinesque, with an analysis of higher groups in the Ictaluridae. Bulletin of the United States National Museum 282:vi + 315.

Thompson, B.A. 1985. Percina jenkinsi, a new species of logperch (Pisces, Percidae) from the Conasauga River, Tennessee and Georgia. Occasional Papers of the Museum of Zoology, Louisiana State University 61:1-23.

Thompson, B.A. 1995. Percina austroperca: a new species of logperch (Percidae, Subgenus Percina) from the Choctawhatchee and Escambia rivers in Alabama and Florida. 
Occasional Papers of the Museum of Natural Science, Louisiana State University 69:1-19.

Vari, R.P., A.S. Harold, and D.C. Taphorn. 1994. Creagrutus melasma, a new species of characid fish (Teleostei: Characiformes) from upland streams of northern Venezuela. Proceedings of the Biological Society of Washington 107(1):90-96.

Warren, M.L., Jr. 1992. Variation of the spotted sunfish, Lepomis punctatus complex (Centrarchidae): meristics, morphometrics, pigmentation and species limits. Bulletin Alabama Museum of Natural History 12:1-47.

Warren, M.L., Jr., B.M. Burr, and J.M. Grady. 1994. Notropis albizonatus, a new cyprinid fish endemic to the Tennessee and Cumberland River drainages, with a phylogeny of the Notropis procne species group. Copeia 1994(4):868-886.

Williams, J.D. 1977. Endangered species: yesterday, today, and tomorrow? Pages 49-55 in J.E. Cooper, S.S. Robinson, and J.B. Funderberg, eds. Endangered and threatened plants and animals of North Carolina. North Carolina State Museum of Natural History, Raleigh.

Williams, J.D., and D.A. Etnier. 1978.

Etheostoma aquali, a new percid fish (subgenus Nothonotus) from the Duck and Buffalo rivers, Tennessee. Proceedings of the Biological Society of Washington 91(2):463-471.

Williams, J.D., and D.A. Etnier. 1982. Description of a new species, Fundulus julisia, with a redescription of Fundulus albolineatus and a diagnosis of the subgenus Xenisma (Teleostei: Cyprinodontidae). Occasional Papers of the Museum of Natural History, University of Kansas 102:1-20.

Williams, J.T. 1996. Fish Collection-Online Search, Division of Fishes, National Museum of Natural History, Smithsonian Institution. http://www.nmnh.si.edu/vert/fishcat/ index.html.
Wood, R.M., and R.L. Mayden. 1993. Systematics of the Etheostoma jordani species group (Teleostei: Percidae), with descriptions of three new species. Bulletin Alabama Museum of Natural History 16:31-46.

Woods, L.P., and R.F. Inger. 1957. The cave, spring, and swamp fishes of the family Amblyopsidae of central and eastern United States. The American Midland Naturalist 58(1):232-256. 

Illinois Natural History Survey

Natural Resources Building

607 East Peabody Drive

Champaign, Illinois 61820

217-333-6880

A Division of the Illinois Department of Natural Resources.

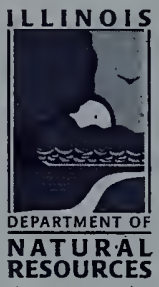

